\title{
The Role of Connections in Congressional
}

\section{Lawmaking *}

\author{
Haritz Garro \\ Stanford University
}

September 14,2020

\begin{abstract}
Understanding what makes legislators effective is a central problem in the congressional literature. However, estimating how connections impact legislative effectiveness is challenging, as unobserved factors influence lawmakers' effectiveness and connections. I investigate the role of connections in congressional lawmaking by studying how legislators' deaths impact their peers' capacity to sponsor and advance bills in the U.S. House of Representatives. I focus on legislators who represent the same states as deceased legislators: these lawmakers collaborated with the deceased more closely, but otherwise they are comparable to all other lawmakers. Following the death of a legislator from the same state, lawmakers suffer a $16 \%$ decrease in their effectiveness. The impacts are concentrated in the initial stages of lawmaking when the support of key lawmakers is crucial to ensure a bill is considered in committee. Moreover, same-state legislators experience a larger decrease in effectiveness after the death of a committee chair.
\end{abstract}

\footnotetext{
*hgarro@stanford.edu. I am grateful to Jörg Spenkuch for valuable guidance and suggestions. I thank Bruno Barsanetti, Janet Box-Steffensmeier, Tim Feddersen, Michael Gmeiner, Justin Grimmer, Nolan McCarty, Matt Notowidigdo, Nicola Persico, Gisela Sin, Steven Smith, Jennifer Victor, and audiences at Northwestern, UCSD GPS, Congress \& History 2020, and APSA 2020 for useful comments.
} 


\section{Introduction}

Lawmakers in Congress do not merely cast their votes on bills that reach the floor. They are also in charge of drafting the initial bills and deciding which bills should receive action in committees, advance to the floor, and ultimately become law. In the same way that legislators differ in their floor voting behavior, they also exhibit sizable differences in their legislative effectiveness-that is, their capacity to sponsor bills and ensure those bills advance through the lawmaking process.

Tom Lantos was a Hungarian Holocaust survivor who represented California in the U.S. House of Representatives from 1981 until his death in 2008. During his long tenure, this effective legislator sponsored numerous human rights bills on issues such as genocide prevention and sanctions for Serbia and Burma. Senator Amy Klobuchar (D-MN) is a persistent lawmaker who has sponsored numerous bills that became law, on various issues-such as human trafficking, drug disposal safety, adoption, and telecommunications quality in rural areas. She is currently one of the most effective senators, despite being in the minority party. ${ }^{1}$ Both Lantos and Klobuchar formed vast networks of legislative connections during their tenure in Congress. Other legislators, by contrast, sponsor bills that hardly ever advance to law, or do not sponsor many bills in the first place.

Some lawmakers are more effective because they have greater abilities, certain individual characteristics, and institutional positions to exercise their influence. But what role do their legislative connections play in enhancing their capacity to sponsor and advance substantive bills? How does the death in office of a prominent legislator, such as Lantos, impact the effectiveness of lawmakers connected to him?

Understanding the factors that contribute to legislative effectiveness is a central aim in the congressional literature (Matthews, 1960; Frantzich, 1979; Hibbing, 1991; Anderson, Box-Steffensmeier and Sinclair-Chapman, 2003). Volden and Wiseman (2014) sys-

\footnotetext{
${ }^{1}$ https : //thelawmakers.org/.
} 
tematically measure lawmakers' effectiveness in the U.S. House of Representatives and study individual characteristics and institutional positions that might explain effectiveness. Such factors include seniority, membership in the majority, and committee chair positions. In addition, the literature on networks has documented a strong correlation between lawmakers' network size and legislative influence (Fowler, 2006a). Nevertheless, legislators endogenously form their networks, which poses a challenge to the identification of the causal effects of networks (Rogowski and Sinclair, 2012). To estimate how legislators' connections impact their effectiveness, researchers must contend with the fact that unobserved traits that affect the size and prominence of legislators' networks, such as innate ability or social skills, are also likely to affect their success in sponsoring substantive bills and advancing them through the lawmaking process. Failure to account for network endogeneity could lead to incorrect inferences about the causal effects of connections.

In this paper, I show that connections substantially affect lawmakers' effectiveness. I propose an empirical strategy that addresses network endogeneity, estimates the value of connections for legislative effectiveness, and uncovers the mechanisms through which connections impact effectiveness. I identify the disruptions to legislative networks caused by deaths of legislators in the U.S. House of Representatives and study how these deaths impact the effectiveness of legislators who represent the same states as the deceased legislators. The rationale for studying legislators from the same states as deceased legislators, rather than legislators directly connected to deceased legislators based on bill cosponsorship measures, is twofold. First, legislators who represent the same states are more likely to collaborate with each other than legislators who represent different states. Same-state legislators often belong to state organizations, are likely to know each other before they arrive in Congress, and tend to represent the interests of districts that have similar needs and characteristics. Second, legislators who represent the same state as a deceased legislator in a particular congress constitute a sample that is comparable to all 
other legislators in the House in that congress. By contrast, legislators who are connected to a deceased legislator are not comparable to non-connected legislators. Well-connected and powerful legislators, by virtue of being connected to many other legislators, are likely to have been connected to the deceased legislator. Crucially, well-connected lawmakers tend to be systematically more senior and more powerful than less connected lawmakers. If the research design does not properly account for this sample selection problem, it produces substantially incorrect estimates.

Lawmakers who represent the same states as deceased legislators experience a sizable $(16 \%)$ decrease in their effectiveness the congress after a legislator passes away. The effects are concentrated on the initial stages of lawmaking, as bills sponsored by samestate lawmakers become less likely to receive action in committee (13\% decrease in the number of sponsored bills that receive action in committee). These results highlight the team-based nature of lawmaking. Legislative connections play a key role during the initial stages since a bill is drafted until it is considered at the committee stage. The findings are consistent with Box-Steffensmeier, Christenson, and Craig (2019), who argue that the support of a select number of influential lawmakers is key for bills to advance the initial lawmaking stages. The decrease in the number of bills that become law is especially large (a 27\% drop) for substantive and significant bills, which are landmark bills that received an end-of-the-year write-up in the Congressional Quarterly Almanac.

Placebo tests indicate that the estimated effects are not attributable to unobserved differences between legislators who were affected and unaffected by the deaths of legislators from the same state. Furthermore, consistent with the hypothesis that connections to deceased legislators drive the observed results on effectiveness, I find that the loss in effectiveness experienced by same-state legislators is larger when the deceased legislator was a committee chair. Chairs are powerful players in Congress (Berry and Fowler, 2018). They exercise both positive and negative agenda control, deciding which bills are considered by their committees and which bills are blocked or disregarded. This also 
gives them power and influence over the chairs and members of other committees. Consequently, when lawmakers lose an influential ally in the House, their capacity to draft and advance legislation is appreciably undermined.

The death of a lawmaker in office induces a significant decrease in the effectiveness of same-state legislators. This effect is larger for same-state, same-party lawmakers, but it also impacts same-state legislators of the opposing party. In a Congress characterized by increasing levels of political polarization and party control of roll-call voting (McCarty, Poole and Rosenthal, 2016), this finding underscores the importance of weak ties and connections that cross the party lines (Harbridge, 2015; Kirkland, 2011). Weak ties formed between legislators that have strong fundamental differences-such as those formed by lawmakers from opposing parties-allow lawmakers to obtain valuable information and gather the support of legislators that would otherwise oppose a bill.

The results also have implications for the long-standing debate on term limits (Carey, 1998). Reformers argue that instituting term limits in Congress would reduce the influence of special interests, as well as induce legislators to spend more time on lawmaking and less on fundraising activities. However, the results in this paper illustrate the importance of long-term relationships in Congress, and suggest that term limits would substantially reduce the overall effectiveness of the legislature both directly-legislators become more effective as they gain seniority—and indirectly-legislators connected to departing senior legislators would lose access to their expertise and vast network of connections.

\section{Related Literature and Theory}

Effective lawmakers play a central role in legislative bodies. They devise solutions to pressing societal problems, gather coalitions to support these solutions, and fight for their proposals throughout the lawmaking process. Eventually, some of these proposals 
become law and bring about meaningful policy change. Understanding what factors influence legislators' effectiveness is important to understand the lawmaking process itself. Hence, it is not surprising that the study of legislative effectiveness has a long history in the literature.

Matthews (1960) provides the first attempt at measuring lawmakers' capacity to advance their bills by creating an index of legislative effectiveness. Frantzich (1979) documents that seniority, majority-party status, and electoral safety are the most important determinants of legislative effectiveness. Hibbing (1991), Anderson, Box-Steffensmeier and Sinclair-Chapman (2003), Padró i Miquel and Snyder (2006), Cox and Terry (2008), and Volden and Wiseman (2014) also study which individual characteristics and institutional positions predict lawmakers' effectiveness in the U.S. House, Senate, and state legislatures.

Although one of lawmakers' most pressing goals is to get reelected (Mayhew, 1974), other key objectives include achieving institutional power, sponsoring substantive bills, and ensuring their passage (Fenno, 1973; 1978). Effective and productive lawmakers bring about policy change and draft bills that, if passed, would advance their policy goals. Legislative effectiveness is valued by voters or it is correlated with traits that voters value. Padró i Miquel and Snyder (2006), Volden and Wiseman (2014), and Fouirnaies and Hall (2018) show that lawmakers' effectiveness in the first term is positively correlated with longevity in the chamber.

In addition to individual characteristics and institutional positions, the literature on networks has shown that lawmakers who have many connections in the House and Senate tend to be more effective than their less-connected peers (Fowler, 2006a; Kirkland, 2011). ${ }^{2}$ Yet, legislative networks are endogenously formed. It is likely that traits that predispose legislators to build large or influential networks also help these lawmakers to be effective. Thus, natural experiments that induce variation in networks are needed to

\footnotetext{
${ }^{2}$ Tam Cho and Fowler (2010) show that Congress as a whole is more productive when legislators are more interconnected in the cosponsorship network.
} 
credibly learn how connections impact legislators' effectiveness. However, recent papers that rely on natural experiments that induce variation in networks have estimated the effects of legislative connections on voting behavior, rather than effectiveness.

Masket (2008) and Harmon, Fisman and Kamenica (2018) show that deskmate pairs influence each other's voting behavior in the California Assembly and the European Parliament, respectively. ${ }^{3}$ Minozzi and Caldeira (2015) show that co-residence in boardinghouses predicts and causes voting agreement in the pre-Civil War U.S. House of Representatives. Fong (2019) shows that lawmakers take cues for voting from expert peers. Cohen and Malloy (2014) show that senators who studied at the same university have higher agreement rates in roll-call votes and engage in logrolling. These papers have studied how networks affect legislators' voting behavior, but to date, little research has been done to estimate the causal effects of connections on legislative effectiveness through natural experiments. Battaglini, Sciabolazza and Patacchini (2019) show that network centrality - which is a measure of the location of a lawmaker in the congressional network of collaborations-improves legislative effectiveness. ${ }^{4}$ They find that the centrality of a lawmaker helps bills progress in the later lawmaking stages. By contrast, I focus on direct connections between pairs of legislators and show instead that connections matter most in the initial stages of lawmaking. The divergent findings for network centrality versus individual connections are consistent with the theoretical framework developed by Box-Steffensmeier, Christenson and Craig (2019). They argue that bill success in the early stages of lawmaking is aided by the support of a small number of influential lawmakers and interest groups. Conversely, the endorsement of a large number of cosponsors is more important in the later stages of lawmaking, when a bill needs to be approved in the House and Senate floors and necessitates broad support.

\footnotetext{
${ }^{3}$ Rogowski and Sinclair (2012), however, find that office proximity-instrumented by the House office lottery-does not impact lawmakers' voting and cosponsorship behavior.

${ }^{4}$ They account for the endogeneity of network centrality by exploiting the tendency of pairs of legislators who studied at the same university around the same time to collaborate. Canen, Jackson and Trebbi (2020) develop a structural model that accounts for the endogenous formation of networks.
} 
The notion that connections are important for effectiveness is theoretically intuitive. The lawmaking process in the U.S. House of Representatives is tortuous. A bill that becomes law must first be introduced into the chamber, considered in committee, sent to the House floor, approved by both chambers, and signed into law by the president. Most bills never receive action in committee. ${ }^{5}$ In light of this lengthy process, legislators must cooperate with each other so that their bills can successfully navigate through the different lawmaking stages. One way in which connections can facilitate a bill's passage is by providing access to influential committee members and committee chairs. They can also promise to cosponsor each other's bills and mobilize resources. Evidence exists that vote trading occurs among connected legislators in Congress (Cohen and Malloy, 2014), and similar dynamics might operate in the lawmaking realm. ${ }^{6}$ Enlisting additional cosponsors could be valuable, as bills supported by a larger number of cosponsors are more likely to pass the later stages of lawmaking (Box-Steffensmeier, Christenson and Craig, 2019). Finally, as lawmakers take cues from their peers to decide their vote on bills for which they lack expertise (Matthews and Stimson, 1975; Fong, 2019), committee members and chairs might also decide to consider a bill based on whether influential lawmakers cosponsored it. Likewise, lawmakers might decide to cosponsor a bill if influential lawmakers cosponsored it early in the lawmaking process.

Another channel through which connections can enhance effectiveness in Congress is information sharing. Information about relevant committee members, the specific content and cosponsors to include in a bill to maximize peer support, or the optimal timing to introduce specific legislation can help legislators to fine-tune their bills to increase their valence and improve their appeal without making large concessions on their policy goals. Although information exchanges in Congress are particularly challenging to

\footnotetext{
${ }^{5}$ Only $17 \%$ of all bills receive action in committee.

${ }^{6}$ Box-Steffensmeier, Campbell, Podob, and Walker (2019) study another form of cooperation among legislators, namely the sharing, trading, or selling of donor and supporter lists between congressional campaigns. They show that this form of electoral collaboration is influenced by similar strategic considerations and dynamics.
} 
observe, researchers have devoted ample attention to studying how information is aggregated by individuals and committees (Krehbiel, 1992; Ainsworth and Akins, 1997; Victor and Ringe, 2009 on the informational role of caucuses).

\section{Endogenous Connections}

The death of a legislator in office constitutes an abrupt disruption to legislative networks, which should be felt especially by lawmakers connected to the deceased legislator. ${ }^{7}$ Accordingly, a seemingly natural approach to identify the effects of losing a legislative connection on effectiveness is to examine how the effectiveness of connected legislators changes-compared with non-connected legislators-after a legislator passes away. Several measures of connections between lawmakers have been used to date, all of which are based on cosponsorship patterns (Fowler, 2006a, 2006b; Battaglini, Sciabolazza and Patacchini, 2019). ${ }^{8}$

In the Appendix, I show that the above approach is deeply flawed and leads to incorrect inferences about the impact of connections on effectiveness. The fundamental problem is that well-connected legislators, by virtue of their many legislative connections, are likely to be connected to legislators who die in office. Likewise, well-connected legislators tend to be senior and powerful members of the House. The imbalance in the characteristics of lawmakers who are affected and unaffected by the deaths of their colleagues implies that the causal effects of connections on effectiveness cannot be es-

\footnotetext{
${ }^{7}$ Previous literature leveraged deaths as network disruptions to estimate the effects of connections on different outcomes. Azoulay, Graff-Zivin, and Wang (2010) analyze how the death of academic superstars affects their collaborators' quality-adjusted publication rates. Fedaseyeu and Lvovskiy (2018) find that firms that contribute to a legislator from the U.S. House of Representatives that dies in office experience a decrease in equity value shortly after the legislator dies. Roberts (1990) leverages the death of Senator Henry "Scoop" Jackson (D-WA) in 1983 to investigate the relationship between seniority and federal benefits. Maltzman, Sigelman, and Binder (1996) provide a fascinating historical account of death in Congress.

${ }^{8}$ Cosponsoring a bill is considered as an endorsement, a signal about its content (Wilson and Young, 1997; Koger, 2003; Bratton and Rouse, 2011), and a commitment of support (Bernhard and Sulkin, 2013). House bills can only have a single legislator as the sponsor, but there are no restrictions on the number of cosponsors.
} 
timated by comparing connected and non-connected legislators. Even in the absence of legislator deaths, more and less connected legislators typically experience different changes in their legislative effectiveness over time. ${ }^{9}$ In the next section, I present a research design that overcomes this sample selection problem and identifies the causal effects of connections on legislative effectiveness.

\section{Same-State Legislators}

As explained in the introduction, the endogenous formation of legislative connections poses an obstacle to assessing how connections impact the effectiveness of legislators in the U.S. House of Representatives. Individual characteristics that affect lawmakers' capacity to form legislative connections likely impact their effectiveness too. As a result, a positive correlation between legislators' connectedness and effectiveness does not imply that connections help lawmakers to be more effective. To estimate the causal effects of connections on effectiveness, I study the legislators who represent the same states as deceased legislators. These legislators collaborated with the deceased legislators more often than legislators from other states, but were otherwise comparable to other legislators. The identifying assumption is that state delegations are quasi-randomly affected by deaths in office: absent the deaths, the effectiveness of legislators from the same states as deceased legislators would have paralleled the effectiveness of other legislators in the House.

\section{Deceased Legislators were more Connected to Same-State Legislators}

First, I show that same-state legislators were more connected to deceased legislators than were legislators from other states. Prior work has established the importance of

\footnotetext{
${ }^{9}$ More connected legislators expand their connections and become more effective and more powerful over time. Less connected legislators, by contrast, wander around Congress crestfallen, cognizant of the dismal fate awaiting their bills and their slim prospects of ever achieving positions of power.
} 
regional relationships in Congress (Pellegrini and Grant, 1999; Fowler, 2006a; Caldeira and Patterson, 1987 and Bratton and Rouse, 2011 for state legislatures). Politicians from contiguous districts or belonging to the same state or regional delegations are likely to know each other before they enter Congress and are likely to represent the interests of similar constituents. Some of the strongest connections in the House tend to occur between pairs of legislators who represent the same state or contiguous districts (Fowler, 2006a). Frequently, strong connections are formed between same-state legislators even when the legislators belong to different parties. Table 1 shows the results of estimating the following model

$$
\text { Connection }_{i, t}=\alpha_{i}+\delta_{t}+\beta \text { Same-State Death } i+\gamma X_{i t}+\epsilon_{i t}
$$

where Connection ${ }_{i, t}$ denotes the number of cosponsorships received by legislator $i$ in congress $t-1$ from legislators who died in congress $t$ (Columns 1 and 2 ) and the number of reciprocal cosponsorships at $t-1$ with legislators who died in congress $t$ (Columns 3 and 4). ${ }^{10}$ Both measures of connection are calculated for the congress before the legislator passed away. ${ }^{11}$ Same-State Death ${ }_{i}$ is equal to 1 if a legislator from the same state as $i$ dies in that congressional term. The terms $\alpha_{i}$ and $\delta_{t}$ denote legislator and congress fixed effects, and $X_{i t}$ denotes a set of legislator-level controls. ${ }^{12}$ Standard errors are clustered at the legislator level to account for arbitrary within-legislator correlation. The sample spans the 1980 to 2010 election cycles and includes the deaths of 45 legislators in the U.S. House of Representatives. ${ }^{13}$

\footnotetext{
${ }^{10}$ The reciprocal cosponsorship variable is calculated as $\min \left\{\operatorname{Cos} p_{i j}, \operatorname{Cos} p_{j i}\right\}$, where $\operatorname{Cos} p_{i j}$ and $\operatorname{Cos} p_{j i}$ denote the number of bills sponsored by legislator $j$ and cosponsored by legislator $i$, and vice versa.

${ }^{11}$ If legislator $i$ was connected to more than one legislator who died in a given congress, the connection variable is the sum of the connections to each deceased legislator.

${ }^{12}$ The control variables include seniority, seniority squared, majority membership, size of the state delegation, vote share in previous election, chair of a committee, chair of a subcommittee, and member of a powerful committee. I explain the rationale for including these control variables later in the "Main Results" section.

${ }^{13}$ The list of legislators that died in office during this period is in Table B.1
} 
Table 1: Same-State Deaths and Legislative Connections

\begin{tabular}{lccccc}
\hline & \multicolumn{2}{c}{ Cosponsorships Received } & & \multicolumn{2}{c}{ Reciprocal Cosponsorships } \\
\cline { 2 - 3 } & $(1)$ & $(2)$ & & $(3)$ & $(4)$ \\
\hline Same-State Death & $0.544^{* *}$ & $0.633^{* *}$ & & $0.265^{* *}$ & $0.294^{* *}$ \\
& $(0.112)$ & $(0.118)$ & & $(0.047)$ & $(0.050)$ \\
\hline Legislator FE & Yes & Yes & & Yes & Yes \\
Congress FE & Yes & Yes & & Yes & Yes \\
Controls & No & Yes & & No & Yes \\
Mean Dependent Variable & 1.05 & 1.05 & & 0.33 & 0.33 \\
Observations & 6800 & 6564 & & 6800 & 6564 \\
\hline
\end{tabular}

Note: The table reports the results of estimating equation 1 . The dependent variable in Columns 1 and 2 is the number of cosponsorships received in congress $t-1$ from legislators who died in congress $t$. The dependent variable in Columns 3 and 4 is the number of reciprocal cosponsorships in congress $t-1$ with legislators who died in congress $t$. The unit of observation is a legislator-congress. Standard errors (in parentheses) are clustered at the legislator level. Significance levels: ${ }^{*} 5 \%,{ }^{* *} 1 \%$

The results show that lawmakers that experienced the death of a same-state legislator were more connected to deceased legislators. Thus, representing the same states as deceased legislators constitutes a strong proxy for being connected to the deceased. ${ }^{14}$

\section{Same-State Legislators are Comparable to Legislators from Other States}

In this section, I conduct a balance test that analyzes whether legislators from the same states as deceased legislators are comparable to all other legislators. Ideally, there should be no systematic differences in the characteristics of treatment and control units. I estimate the following equation

$$
\text { Effectiveness }_{i t}=\delta_{t}+\beta \text { Same-State Death }_{i}+\gamma X_{i t}+\epsilon_{i t}
$$

which does not include legislator fixed effects. Same-State Death $h_{i}$ is equal to 1 if a leg-

\footnotetext{
${ }^{14}$ In Table D.1 in the Appendix I analyze the full sample of legislator dyads and confirm that pairs of legislators who represent the same states collaborate more often than pairs of legislators who represent different states. The pattern of stronger collaborations among same-state legislators holds for all legislators in the U.S. House of Representatives, not only for deceased legislators.
} 
islator from the same state as $i$ dies in that congressional term. Equation 2 tests whether the effectiveness scores of treatment legislators differed systematically from the scores of control legislators. Effectiveness ${ }_{i t}$ denotes the legislative effectiveness score of legislator $i$ in congress $t$. The scores-which were obtained from the Legislative Effectiveness Project (Volden and Wiseman, 2014) - are calculated as weighted sums of the number of bills sponsored by a legislator in a congress, the importance of those bills, and how far they advanced through the lawmaking stages. The scores are normalized so that the mean score in each congress is equal to 1 .

Table 2: Same-State Balance Table

\begin{tabular}{lccc}
\hline & \multicolumn{3}{c}{ Legislative Effectiveness } \\
\cline { 2 - 4 } & $(1)$ & $(2)$ & $(3)$ \\
\hline Same-State Death & 0.041 & 0.040 & 0.053 \\
& $(0.059)$ & $(0.052)$ & $(0.044)$ \\
Seniority & & $0.153^{* *}$ & $0.063^{* *}$ \\
& & $(0.013)$ & $(0.018)$ \\
\hline Legislator FE & No & No & No \\
Congress FE & Yes & Yes & Yes \\
Controls & No & No & Yes \\
Observations & 7048 & 7034 & 6827 \\
\hline
\end{tabular}

Note: The table reports the results of a balance test. The unit of observation is a legislatorcongress. Standard errors (in parentheses) are clustered at the legislator level. Significance levels: ${ }^{*} 5 \%,{ }^{* *} 1 \%$

The results are shown in Table 2. The first column shows that legislators impacted by same-state deaths were slightly more effective than all other legislators, but the difference is not statistically significant. Columns 2 and 3 also show a small but insignificant effectiveness difference after controlling for seniority and further legislator-level variables. The results indicate that legislators from the same and different states as deceased legislators, respectively, constitute appropriate treatment and control groups to determine whether losing a connection impacts lawmakers' effectiveness. 


\section{Main Results}

In the previous sections, I showed that legislators from the same states as deceased legislators were more connected to the deceased, but were otherwise comparable to all other legislators. In this section, I examine how these lawmakers' effectiveness scores were affected by their same-state peers' deaths by estimating the following model

$$
\text { Effectiveness }_{i t}=\alpha_{i}+\delta_{t}+\sum_{s=-1}^{1} \beta_{s} \text { Same-State Death }_{i, s}+\gamma X_{i t}+\epsilon_{i t}
$$

where Same-State Death ${ }_{i, s}$ denote indicator variables that capture legislators impacted by same-state deaths one congressional term before the deaths, during the term, and one term after the deaths. The terms $\alpha_{i}$ and $\delta_{t}$ denote legislator and congress fixed effects and $X_{i t}$ denotes a set of legislator-level controls. Standard errors are clustered at the legislator level. ${ }^{15}$

The legislator fixed effects, $\alpha_{i}$, are included to account for time-invariant, legislatorlevel traits that impact their effectiveness and connections. Thus, the estimation exploits within-legislator variation in exposure to the loss of a connection and effectiveness. The congress fixed effects, $\delta_{t}$, absorb yearly common shocks. Same-State Death $h_{i,-1}$ is added to test for differential pre-treatment trends between treatment and control legislators. Same-State Death ${ }_{i, 0}$ and Same-State Death ${ }_{i, 1}$ test for impacts of legislator deaths on the effectiveness of same-state legislators in the congress in which the legislators died and the next congress, respectively. The control variables, $X_{i t}$, include seniority and its squared value to control for common non-linear effectiveness trajectories throughout legislators' careers; an indicator variable for majority membership; size of the state delegation; ${ }^{16}$ vote share in the previous general election; and indicator variables for whether the leg-

\footnotetext{
${ }^{15}$ The results are robust to clustering standard errors at the state, state-congress, and two-way legislator and state-congress levels, as shown in Table E.1 in the Appendix. In all these cases, the standard errors of the main explanatory variables are smaller than the errors in the main specification.

${ }^{16}$ The size of the state delegation is mostly constant over time, and thus absorbed by the legislator fixed effects. However, it sometimes changes after redistricting.
} 
islator was the chair of a committee, chair of a subcommittee, or member of a powerful committee (Rules, Appropriations, and Ways and Means). These last control variables account for changes in legislative effectiveness scores attributable to changes in the institutional positions of legislators. Majority status, seniority, electoral security, committee leadership positions, and membership in powerful committees are major determinants of effectiveness (Volden and Wiseman, 2014).

Table 3 displays the results of estimating equation 3. Lawmakers from the same states as deceased legislators experience a significant decrease in their effectiveness scores in the congress after the deaths. The results are robust to the inclusion of control variables. The estimated decrease in effectiveness after the death of a same-state legislator is sizable: the coefficient for Same-State Death ${ }_{i, 1}$ in Column 5 is -0.159 . Figure 1 plots the results in Column 5. For comparison, the within-legislator standard deviation of effectiveness is 1.16, the mean effectiveness score in each congress is 1 , and majority membership increases effectiveness by 0.67 points. The effects are thus substantial, especially as they pertain to the death of a single lawmaker in a legislature composed of 435 members. To put the -0.159 estimate in context, the set of same-state legislators likely includes lawmakers who had negligible or no legislative connections with deceased legislators. At the same time, deceased legislators had many close connections to lawmakers who represented different states. The estimate only partially captures the impact of losing a connection on effectiveness. ${ }^{17}$

The estimate for Same-State Death -1 is equal to zero, indicating that legislators who were impacted by same-state deaths displayed similar pre-treatment trends to all other legislators. This finding bolsters confidence in the identifying assumption that, absent the legislator deaths, same-state legislators' effectiveness scores would have followed parallel trends relative to all other legislators. Finally, the coefficient for Same-State Death $h_{i, 0}$

\footnotetext{
${ }^{17}$ Admittedly, deceased legislators were more senior and powerful than average legislators. As a result, their deaths are likely to have had more substantial effects on their connections. The results in Column 1 of Table 6 confirm that the deaths of more influential lawmakers have larger effects on same-state legislators.
} 
Table 3: Effect of Death of Same-State Legislator on Effectiveness

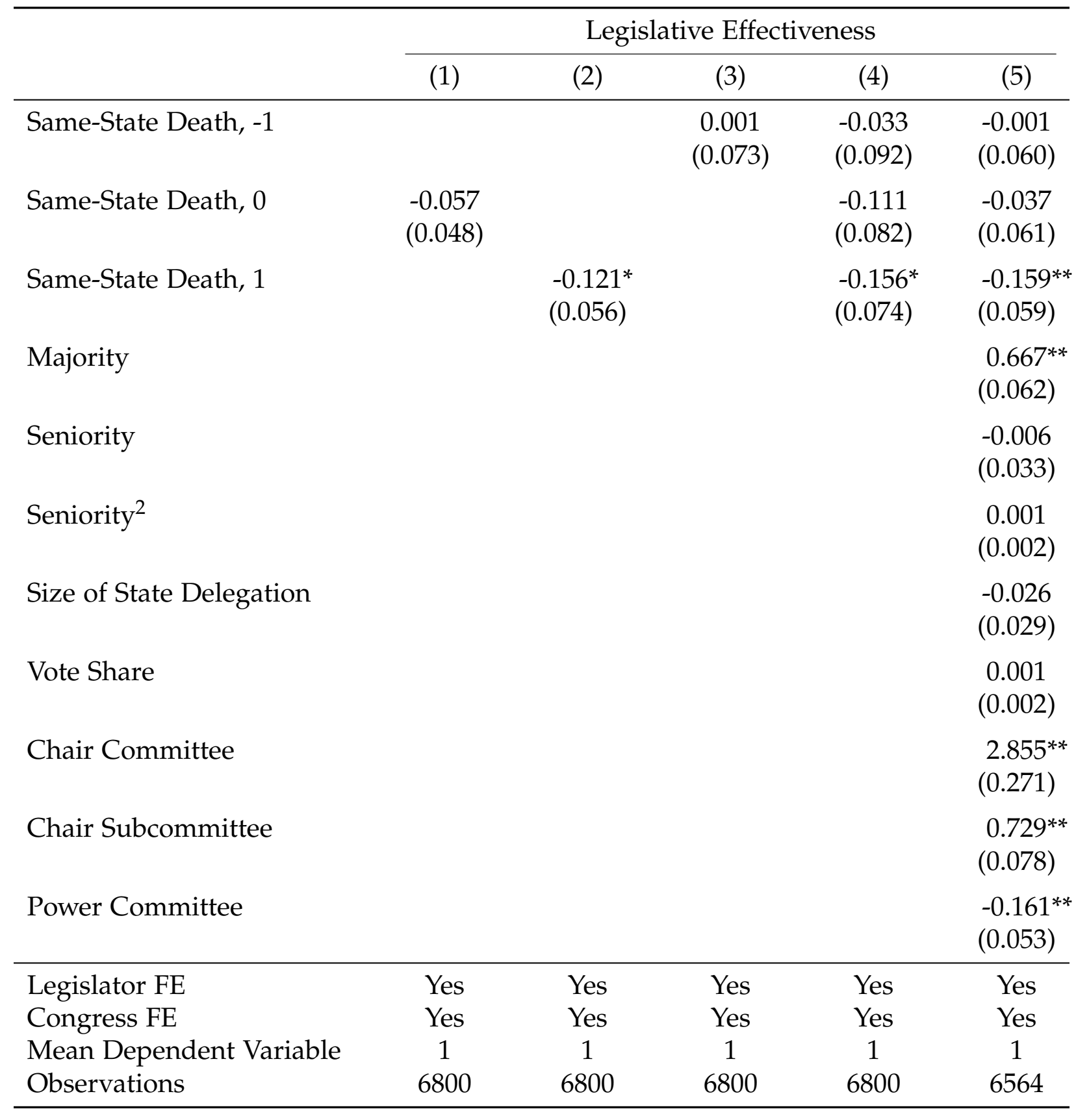

Note: The table reports the results of estimating equation 3 . The unit of observation is a legislator-congress. Standard errors (in parentheses) are clustered at the legislator level. Significance levels: ${ }^{*} \%,{ }^{* *} 1 \%$

is negative but small and insignificant. Legislators who passed away in office worked in the House for at least some part of the congress during which they died, and most bills 
Figure 1: Plot of the Effect of the Death of a Same-State Legislator on Effectiveness

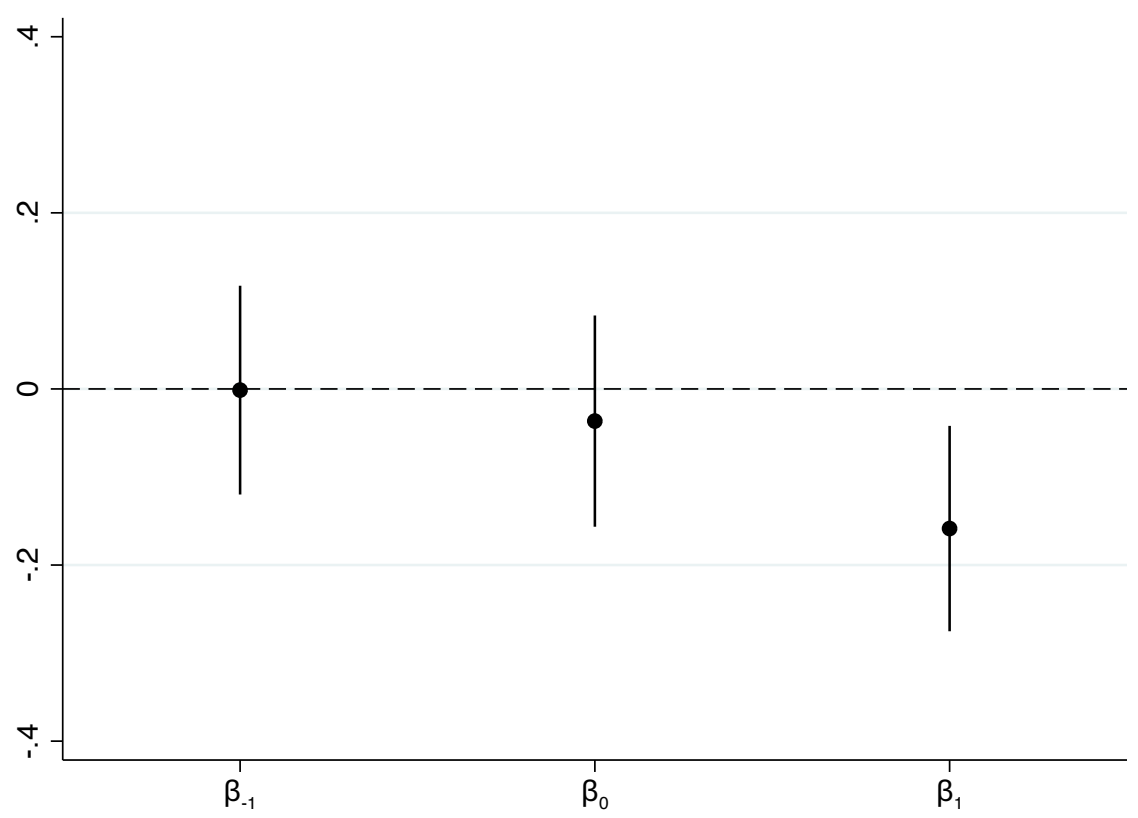

Note: This figure depicts the $\beta$ estimates of equation 3 (Column 5 of Table 3).

are introduced to the House early in the congressional term. ${ }^{18}$ It is thus not surprising that the effects for Same-State Death ${ }_{i, 0}$ are small.

Figure 2 instead plots the estimates for Same-State Death ${ }_{i, s}, s=\{-2,-1,0,1,2\}$. The same pattern persists: lawmakers impacted by the death of a same-state legislator experience a sizable decrease in their effectiveness scores the congress after the deaths, and the effect persists even after two congressional terms. In the remainder of the paper, I conduct additional analyses, explore effect heterogeneity, test alternative mechanisms, and argue that the loss of legislative connections is the main channel behind the observed effects.

\footnotetext{
${ }^{18}$ When a congressional term ends, all bills which have not been signed into law are archived, regardless of their status. When Congress reconvenes, a bill has to be reintroduced as if it were a new bill.
} 
Figure 2: Plot of the Effect of the Death of a Same-State Legislator on Effectiveness (5 periods)

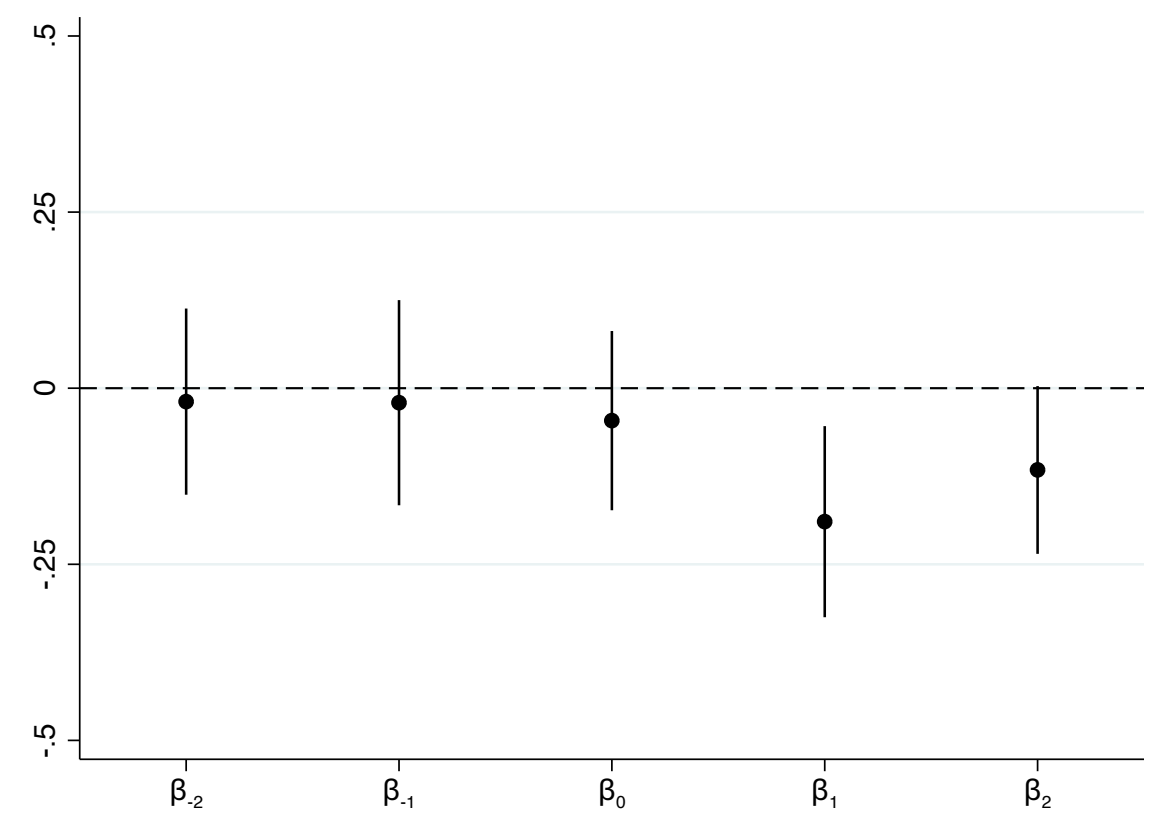

Note: This figure depicts the same estimates as in Figure 1, but with 5 periods. 
Figure 3 plots the distributions of 10,000 placebo estimates for each $\beta_{s}$ associated with Same-State Death ${ }_{i, s}, s=\{-1,0,1\}$, together with the point estimates obtained with actual data (dashed lines). As 45 deaths of legislators occurred during the period under study, each placebo estimate is obtained by randomly selecting a set of 45 legislators at certain congresses as deceased, and computing the resulting treatment and control units based on the states the randomly chosen legislators represented. The legislators who died in office were more senior than the average legislator in the House. Accordingly, in the placebo simulations, I randomly select sets of deceased legislators from the pool of legislators who were serving their fourth term in office, or a subsequent term. With this constraint, the seniority of the simulated sets of deceased legislators is similar to that of the actually deceased.

The placebo distributions reflect the sample variability of the $\beta_{s}$ estimates and should have a mean value of 0 . The sets of legislators considered as treated or not treated in each simulation are random. Therefore, the effectiveness scores of the two groups should exhibit parallel trends, on average. Figure 3 shows that the placebo distributions for the three Same-State Death ${ }_{i, s}, s=\{-1,0,1\}$ estimates are indeed centered around zero. Furthermore, the actual coefficient of -0.159 for Same-State Death $h_{i, 1}$ stands out as an outlier among the simulation estimates; only 49 of the 10,000 simulations $(0.49 \%)$ yielded an estimate having a higher absolute value. In the absence of any effect, it would have been highly unlikely to obtain such an extreme estimate by chance.

The null hypothesis $\left(H_{0}: \beta_{s}=0, s=\{-1,0,1\}\right)$ is rejected in $3.07 \%, 3.01 \%$, and $3.34 \%$ of the placebo simulations. These numbers are relatively close to the $5 \%$ theoretical size and indicate that the research design slightly under-rejects the null hypothesis of no effects. If anything, this suggests that the estimated standard errors are too large. Overall, the placebo exercise shows that the negative and significant estimate for Same-State Death $h_{i, 1}$ in Table 3 is not driven by unobserved differences between lawmakers 
Figure 3: Placebo Distributions of Same-State Death ${ }_{i, s}$

(a) Distribution of Same-State Death $h_{i,-1}$ estimates

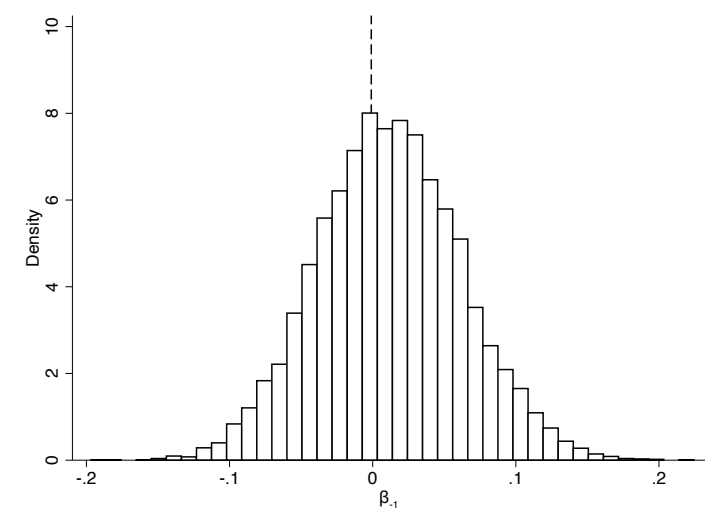

(b) Distribution of Same-State Death ${ }_{i, 0}$ estimates

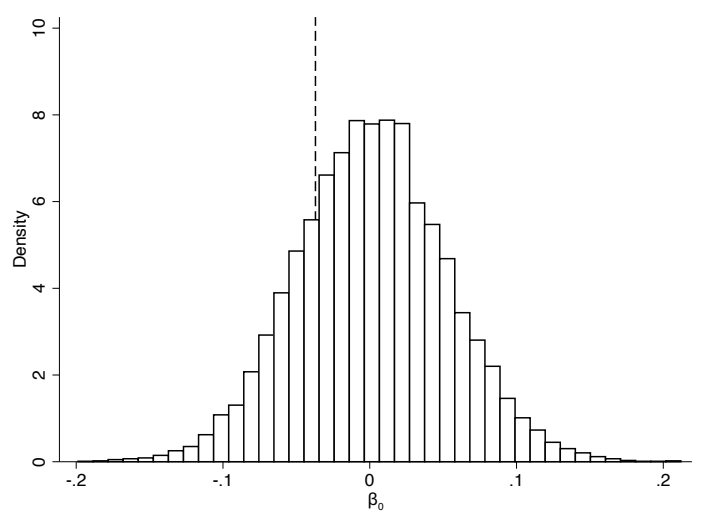

(c) Distribution of Same-State Death $h_{i, 1}$ estimates

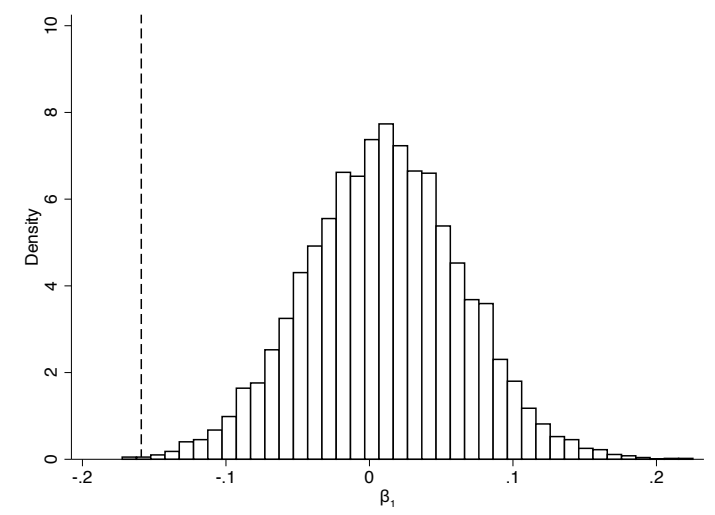

Note: These figures plot the distributions of the placebo point estimates for Same-State Death $h_{i, s}$. The dashed lines denote the point estimates obtained with actual data. The distributions are based on 10,000 simulations.

affected and unaffected by the deaths of same-state legislators. 


\section{Additional Results}

In the next subsections, I explore how lawmakers' deaths in office differentially impact same-state legislators' efforts to advance bills through the lawmaking stages. I also analyze what type of bills are most affected, and under what circumstances the effects on same-state legislators are larger. Overall, the results are consistent with the hypothesis that legislative connections are the main channel through which lawmakers' deaths in office impact same-state legislators' effectiveness.

\section{Lawmaking Stages}

A bill that becomes law needs to first go through several lawmaking stages. To identify the channels through which deceased legislators contributed to the lawmaking success of legislators who represent the same states, I conduct a stage-by-stage analysis of the main effects.

Column 1 of Table 4 shows the estimates for the same specification as in equation 3 , with the effectiveness scores in the dependent variable replaced by the number of bills sponsored. The results show that lawmakers sponsor fewer bills in the congress after a same-state legislator died. The coefficient of -1.34 constitutes a 10\% decrease (lawmakers on average sponsor 13.7 bills per congress). Column 5 shows that the number of bills sponsored by same-state legislators that become law decreases by $16 \% .{ }^{19}$ These two results show that the death of a legislator from the same state not only affects lawmakers' capacity to sponsor bills, but also markedly undermines their efforts to advance those bills through the lawmaking process.

Table 4 further shows that the death of a same-state legislator exerts an especially large impact on lawmakers' effectiveness in the early stages of lawmaking. The number

\footnotetext{
${ }^{19}-0.11$ vs 0.68 sponsored bills that become law per congress, i.e. a $16 \%$ decrease.
} 
Table 4: Lawmaking Stages

\begin{tabular}{|c|c|c|c|c|c|}
\hline & $\underline{\text { Sponsor }}$ & $\begin{array}{c}\text { Action In } \\
\text { Committee } \\
\end{array}$ & $\begin{array}{c}\text { Action Beyond } \\
\text { Committee } \\
\end{array}$ & Pass House & Law \\
\hline & $(1)$ & (2) & (3) & (4) & (5) \\
\hline Same-State Death, -1 & $\begin{array}{l}-0.454 \\
(0.360)\end{array}$ & $\begin{array}{l}-0.030 \\
(0.128)\end{array}$ & $\begin{array}{l}-0.050 \\
(0.108)\end{array}$ & $\begin{array}{l}-0.081 \\
(0.092)\end{array}$ & $\begin{array}{c}0.039 \\
(0.050)\end{array}$ \\
\hline Same-State Death, 0 & $\begin{array}{l}-0.692 \\
(0.405)\end{array}$ & $\begin{array}{l}-0.039 \\
(0.133)\end{array}$ & $\begin{array}{l}-0.028 \\
(0.114)\end{array}$ & $\begin{array}{l}-0.021 \\
(0.097)\end{array}$ & $\begin{array}{c}0.031 \\
(0.055)\end{array}$ \\
\hline Same-State Death, 1 & $\begin{array}{l}-1.340^{* *} \\
(0.343)\end{array}$ & $\begin{array}{l}-0.298^{*} \\
(0.127)\end{array}$ & $\begin{array}{c}-0.263^{*} \\
(0.111)\end{array}$ & $\begin{array}{l}-0.233^{*} \\
(0.092)\end{array}$ & $\begin{array}{l}-0.112^{*} \\
(0.056)\end{array}$ \\
\hline Legislator FE & Yes & Yes & Yes & Yes & Yes \\
\hline Congress FE & Yes & Yes & Yes & Yes & Yes \\
\hline Controls & Yes & Yes & Yes & Yes & Yes \\
\hline Mean Dependent Variable & 13.68 & 2.28 & 1.72 & 1.39 & 0.68 \\
\hline Observations & 6564 & 6564 & 6564 & 6564 & 6564 \\
\hline
\end{tabular}

Note: The dependent variables in Columns 1-5 are the number of bills that 1) were sponsored by the legislator, 2) were sponsored by the legislator and received action in committee, 3) received action beyond committee, 4) passed the House, and 5) became law. The unit of observation is a legislator-congress. Standard errors (in parentheses) are clustered at the legislator level. Significance levels: ${ }^{*} 5 \%,{ }^{* *} 1 \%$

of bills sponsored by same-state legislators that receive action in committee decreases by 0.298 , which constitutes a $13 \%$ decrease relative to the mean number of sponsored bills that receive action in committee ( 2.3 bills). By contrast, conditional on bills receiving action in committee, deaths of same-state legislators only slightly impacts the probabilities of bill progression.

Deaths of same-state legislators impact lawmakers' capacity to draft bills and advance them to the committee stage. The decrease in the number of bills sponsored could be explained by the fact that connected lawmakers sometimes collaborate with each other to draft bills. Furthermore, lawmakers might anticipate their bills will be less likely to be considered in committee after the death of an ally and might, as a result, decide to exert lower effort in sponsoring bills. The decrease in the number of bills sponsored by same-state legislators that receive action in committee illustrates the key role played by 
legislative allies in ensuring bills are considered by the relevant committees. Committee chairs are powerful gatekeepers (Berry and Fowler, 2018; Volden and Wiseman, 2014), and first- or second-degree legislative connections with committee members or committee chairs can facilitate a bill's journey to the relevant committee. Lorenz (2020) shows that agenda-setters are more likely to allocate committee consideration to legislation that is supported by a diverse coalition. Connections to other lawmakers in the chamber can help sponsors mobilize a diverse coalition of interests in favor of a bill.

\section{Types of Bills}

The legislative effectiveness scores developed by Volden and Wiseman (2014) assign different weights to bills depending on their importance. They classify bills as commemorative, substantive, or substantive and significant. Bills categorized as "commemorative" propose to rename post offices, commemorate important dates, or provide private relief to an individual. "Substantive and significant" bills refer to non-commemorative bills that received an end-of-the-year write-up in the Congressional Quarterly Almanac. "Substantive" bills consist of commemorative bills that received a CQ Almanac write-up and any bill not included in the other two categories.

In Table 5, I decompose the results for the number of sponsored bills and bills that become law according to the bill categories. The results show that the deaths of samestate legislators have no discernible effects on commemorative bills. For substantive bills, the number of sponsored bills significantly decreases. The number of substantive bills that become law also decreases, although the estimate is not statistically significant. As for substantive and significant bills, both the number of sponsored bills (16\% drop) and bills that become law decrease ( $27 \%$ drop). The latter estimate is significant at the $10 \%$ level. The decrease in the number of substantive and significant bills sponsored might indicate that the loss of a connection impacts the quality of sponsored bills. However, the 
Table 5: Significant, Substantive, and Commemorative Bills

\begin{tabular}{lcccccc}
\hline & \multicolumn{6}{c}{ Significant, Substantive, and Commemorative Bills } \\
\cline { 2 - 7 } & $(1)$ & $(2)$ & $(3)$ & $(4)$ & $(5)$ & $(6)$ \\
& Bills SS & Law SS & Bills S & Law S & Bills C & Law C \\
\hline Same-State Death, -1 & -0.002 & 0.027 & -0.506 & 0.015 & 0.053 & -0.004 \\
& $(0.082)$ & $(0.036)$ & $(0.336)$ & $(0.035)$ & $(0.060)$ & $(0.020)$ \\
Same-State Death, 0 & -0.026 & -0.002 & -0.671 & 0.004 & 0.005 & 0.030 \\
& $(0.078)$ & $(0.033)$ & $(0.376)$ & $(0.037)$ & $(0.069)$ & $(0.022)$ \\
Same-State Death, 1 & -0.121 & -0.063 & $-1.191^{* *}$ & -0.031 & -0.028 & -0.018 \\
& $(0.086)$ & $(0.034)$ & $(0.311)$ & $(0.035)$ & $(0.069)$ & $(0.018)$ \\
\hline Legislator FE & Yes & Yes & Yes & Yes & Yes & Yes \\
Congress FE & Yes & Yes & Yes & Yes & Yes & Yes \\
Controls & Yes & Yes & Yes & Yes & Yes & Yes \\
Mean Dependent Variable & 0.74 & 0.23 & 12.17 & 0.30 & 0.77 & 0.15 \\
Observations & 6564 & 6564 & 6564 & 6564 & 6564 & 6564 \\
\hline
\end{tabular}

Note: The dependent variables in Columns 1-6 are the number of 1) substantive and significant (SS) bills sponsored by the legislator, 2) SS bills that became law, 3) substantive (S) bills sponsored, 4) S bills that became law, 5) commemorative (C) bills sponsored, and 6) $\mathrm{C}$ bills that became law. The unit of observation is a legislator-congress. Standard errors (in parentheses) are clustered at the legislator level. Significance levels: ${ }^{*} 5 \%,{ }^{* *} 1 \%$

decrease in the number of substantive and significant bills that become law is relatively larger. This suggests lawmakers affected by the death of a legislator from the same state find it more difficult to advance their high-quality bills. Losing a connection critically impacts lawmakers' capacity to advance bills through the lawmaking stages, especially for landmark bills that propose far-reaching policy changes.

\section{Chairs and Issue Areas}

If the decrease in effectiveness suffered by lawmakers impacted by deaths of same-state legislators can be attributed to losing access to relevant committee members and influential lawmakers or to losing the signaling value of the cosponsorships and endorsements provided by deceased lawmakers, we should expect especially large effects when powerful lawmakers die. Powerful lawmakers have a wide network of connections whom 
they can persuade, and can also wield influence over their connections. I examine this hypothesis in Column 1 of Table 6 by testing whether the decreases in effectiveness experienced by same-state legislators were larger when deceased lawmakers held a chair of a legislative committee at some point during their careers. ${ }^{20}$ The results support the hypothesis. Legislators from the same states as deceased committee chairs experience a significantly larger decrease in effectiveness compared to the decrease experienced by legislators impacted by the death of a same-state non-chair legislator. Legislators' capacity to advance bills through the lawmaking process particularly suffers when they lose a powerful and influential ally in Congress. Box-Steffensmeier, Christenson and Craig (2019) argue that endorsements from well-connected interest groups serve as cues that help grow the list of bill cosponsors. Likewise, the endorsement and support of influential lawmakers-committee chairs-contributes to the advancement of bills through the early lawmaking stages.

If connections help lawmakers become more effective because of the information they provide on the specific content to include in bills, which lawmakers to contact for cosponsorship support, or about members of the relevant committee, we should expect the assistance provided by the connection to be especially valuable on issue areas in which the connection is an expert. In turn, an overlap in issue expertise between deceased and same-state legislators should predict larger adverse effects of deaths on lawmakers' effectiveness scores: lawmakers that specialize in similar issue areas would benefit the most from the mutual exchange of information and assistance. To test this hypothesis, I leverage data from the Congressional Bills Project (Adler and Wilkerson, 2015) to identify the issue areas in which the deceased and same-state legislators specialized. Each house bill is classified into one of 22 categories, such as agriculture, civil rights, energy, immigration, defense, and housing. ${ }^{21}$ I calculate the number of bills sponsored

\footnotetext{
${ }^{20}$ I consider committee chair positions held during the 1973-2010 period.

${ }^{21}$ The full set of categories is listed in the "Data Sources" section of the Appendix.
} 
Table 6: Comparative Statics

\begin{tabular}{|c|c|c|c|c|}
\hline & \multicolumn{4}{|c|}{ LES } \\
\hline & (1) & (2) & (3) & (4) \\
\hline Same-State Death, -1 & $\begin{array}{c}0.028 \\
(0.067)\end{array}$ & $\begin{array}{c}-0.006 \\
(0.083)\end{array}$ & $\begin{array}{c}0.016 \\
(0.097)\end{array}$ & $\begin{array}{c}0.067 \\
(0.080)\end{array}$ \\
\hline Same-State Death, 0 & $\begin{array}{c}0.012 \\
(0.069)\end{array}$ & $\begin{array}{l}-0.029 \\
(0.079)\end{array}$ & $\begin{array}{c}-0.003 \\
(0.085)\end{array}$ & $\begin{array}{l}-0.026 \\
(0.090)\end{array}$ \\
\hline Same-State Death, 1 & $\begin{array}{c}-0.072 \\
(0.071)\end{array}$ & $\begin{array}{c}-0.159^{*} \\
(0.077)\end{array}$ & $\begin{array}{c}-0.072 \\
(0.080)\end{array}$ & $\begin{array}{c}-0.118 \\
(0.080)\end{array}$ \\
\hline Same-State Death, $-1 \times$ Deceased Chair & $\begin{array}{c}-0.142 \\
(0.143)\end{array}$ & & & \\
\hline Same-State Death, $0 \times$ Deceased Chair & $\begin{array}{c}-0.195 \\
(0.146)\end{array}$ & & & \\
\hline Same-State Death, $1 \times$ Deceased Chair & $\begin{array}{l}-0.290^{*} \\
(0.146)\end{array}$ & & & \\
\hline Same-State Death, $-1 \times$ Issue Overlap & & $\begin{array}{c}0.010 \\
(0.107)\end{array}$ & & \\
\hline Same-State Death, $0 x$ Issue Overlap & & $\begin{array}{c}-0.015 \\
(0.108)\end{array}$ & & \\
\hline Same-State Death, $1 \times$ Issue Overlap & & $\begin{array}{l}-0.000 \\
(0.096)\end{array}$ & & \\
\hline Same-State Death, $-1 \times$ Copartisan & & & $\begin{array}{c}-0.031 \\
(0.117)\end{array}$ & \\
\hline Same-State Death, 0 x Copartisan & & & $\begin{array}{c}-0.054 \\
(0.118)\end{array}$ & \\
\hline Same-State Death, 1 x Copartisan & & & $\begin{array}{c}-0.150 \\
(0.108)\end{array}$ & \\
\hline Same-State Death, $-1 \times$ Post-1994 & & & & $\begin{array}{l}-0.166 \\
(0.168)\end{array}$ \\
\hline Same-State Death, 0 x Post-1994 & & & & $\begin{array}{c}-0.020 \\
(0.181)\end{array}$ \\
\hline Same-State Death, 1 x Post-1994 & & & & $\begin{array}{c}-0.106 \\
(0.152) \\
\end{array}$ \\
\hline Legislator FE & Yes & Yes & Yes & Yes \\
\hline Congress FE & Yes & Yes & Yes & Yes \\
\hline Controls & Yes & Yes & Yes & Yes \\
\hline Observations & 6564 & 6564 & 6564 & 6564 \\
\hline
\end{tabular}

Note: The dependent variable is the legigfative effectiveness score of legislator $i$ in congress $t$. The unit of observation is a legislator-congress. Standard errors (in parentheses) are clustered at the legislator level. Significance levels: ${ }^{*} 5 \%, * * 1 \%$ 
by each legislator during her career and consider the three issue areas in which she has sponsored most bills as her areas of issue expertise. ${ }^{22}$ Then, for each of the 45 lawmakers who died in office, I identify the same-state legislators that have at least one expert issue area in common. In Column 2 of Table 6 I differentially test whether same-state legislators who had greater overlap in issue expertise were more adversely impacted by the deaths. However, the results do not support this hypothesis, which suggests that the access and cue-taking channels are more prevalent than the information channel.

\section{Political Polarization and the Value of Connections}

Kirkland (2011) argues that weak legislative ties-ties formed by pairs of legislators who interact infrequently, such as those formed by legislators who represent opposing parties-are more valuable than strong ties in achieving legislative success. Column 3 of Table 6 shows that same-state legislators who represent the same party as deceased legislators experience larger decreases in their legislative effectiveness compared to samestate legislators of the opposing party. The estimate for same-state, same-party legislators is three times larger, ${ }^{23}$ although it is not significantly different from the estimate for same-state, different-party legislators. As copartisan legislators collaborate significantly more than do pairs of legislators from different parties, ${ }^{24}$ the result in Column 3 hints that cross-party, same-state connections are also valuable. In times of increasing political polarization between Democrats and Republicans, weak ties and cross-party connections can serve as bridges that build broad coalitions in support of substantive legislation.

In Column 4 of Table 6 I test whether the value of connections changed after the 1994 revolution in which Republicans regained the control of the House and Senate. Newt Gingrich instituted 6-year term limits on committee chairs and gained control of the

\footnotetext{
${ }^{22}$ I compute lawmakers' issue expertise using bills sponsored in the 1973-2010 period.

$23-0.22$ versus -0.072 .

${ }^{24}$ Column 4 of Table D. 1 in the Appendix shows that same-party pairs are $118 \%$ more connected in terms of reciprocal cosponsorships.
} 
committee chair nomination process in an attempt to increase parties' influence in lawmaking at the expense of committee chairs. ${ }^{25}$ At the same time, legislative polarization in the House of Representatives has steadily risen, a trend that was exacerbated by the nationalization of campaigns promoted by Gingrich in 1994. The evidence in Column 4 indicates that, if anything, connections have become more valuable after 1994, although the difference between both periods is not significant.

One potential factor that might explain why the value of connections has increased over time is that lawmakers have less time and resources to read the bills that are introduced in Congress. As a result of ever-increasing fundraising demands-either to secure reelection facing tough challenger competition or to bid for party leadership and committee positions (Heberlig, 2003) - and a decrease in the number of professional staff in the House of Representatives ${ }^{26}$ lawmakers have less time for policy analysis and increasingly rely on interest groups, committee reports, and cues from colleagues and party leadership to decide which bills they should endorse and support (Box-Steffensmeier, Christenson and Craig, 2019). In this environment, the success of a bill might increasingly hinge on the endorsement and support of influential connections at the expense of the content and intrinsic value of the policy proposal.

\section{Alternative Channels and Other Outcomes}

In the next subsections, I examine alternative channels through which lawmakers' deaths in office might have impacted same-state legislators' effectiveness. I also analyze alternative outcomes such as reelection probabilities.

\footnotetext{
${ }^{25}$ Berry and Fowler (2018) study whether committee chairs' power decreased after the 1994 Republican revolution. They find that becoming chair of a committee leads to a lower increase in contributions post1994, but a larger increase in effectiveness.

${ }^{26}$ In 1985 there were 11,537 professional staff workers. In 2015, the number decreased to 7,703 (BoxSteffensmeier, Christenson and Craig, 2019).
} 


\section{Bill Cosponsorship, Committees, and Campaign Contributions}

How do lawmakers' deaths in office impact same-state legislators' capacity to collaborate with other lawmakers? It is possible that the loss of a connection affects the number of bills cosponsored by same-state legislators and the number of cosponsorships they are able to gather for their own bills. Column 1 of Table 7 shows that the number of bills cosponsored by same-state legislators increases slightly in the congress after the death, but the estimate is not statistically significant. The finding suggests that samestate legislators actively seek to establish new legislative connections or strengthen their current connections to make up for the loss of a connection. Such efforts plausibly result in a slightly higher number of cosponsors for their sponsored bills, as suggested by Column 2.

A possible explanation why deaths in office impact same-state lawmakers' effectiveness is that the loss of an ally might adversely impact their chances of obtaining coveted committee or subcommittee chair positions. As shown in Table 3, chairing a committeeand, to a lesser extent, a subcommittee-increases lawmakers' effectiveness. ${ }^{27}$ While Column 3 in Table 7 shows that same-state legislators are not less likely than other legislators to be chairs of a committee in the congress after the death of a lawmaker, Column 4 shows that they are significantly less likely to be chairs of a subcommittee (3.2 percentage points decrease). Nonetheless, a back-of-the-envelope calculation indicates that this effect can only account for $15 \%$ of the decrease in effectiveness experienced by same-state legislators. ${ }^{28}$

The loss of a legislative ally might also impact lawmakers' fund-raising capacity, as legislative connections facilitate access to PACs and prominent individual donors. However, deaths of same-state legislators do not significantly affect the amount of con-

\footnotetext{
${ }^{27}$ See also Volden and Wiseman (2014).

${ }^{28}-0.032 \times 0.729$ (subcommitte chair premium from Table 3 ) $=-0.023$, which is $15 \%$ of -0.159 .
} 
Table 7: Bills, Committees and Money

\begin{tabular}{|c|c|c|c|c|c|c|}
\hline & $\begin{array}{c}\text { \# Bills } \\
\text { Cosp } \\
(1)\end{array}$ & $\begin{array}{c}\begin{array}{c}\text { Avg \# } \\
\text { Cosp }\end{array} \\
\frac{(2)}{}\end{array}$ & $\begin{array}{c}\text { Comm } \\
\text { Chair } \\
(3)\end{array}$ & $\begin{array}{c}\begin{array}{c}\text { Subcomm } \\
\text { Chair }\end{array} \\
(4)\end{array}$ & $\frac{\text { Money }}{(5)}$ & $\frac{\text { Majority }}{(6)}$ \\
\hline Same-State Death, -1 & $\begin{array}{c}0.165 \\
(3.362)\end{array}$ & $\begin{array}{c}0.190 \\
(0.678)\end{array}$ & $\begin{array}{c}0.003 \\
(0.012)\end{array}$ & $\begin{array}{c}0.024 \\
(0.017)\end{array}$ & $\begin{array}{c}25.848 \\
(21.984)\end{array}$ & $\begin{array}{l}-0.037 \\
(0.022)\end{array}$ \\
\hline Same-State Death, 0 & $\begin{array}{l}-0.665 \\
(4.103)\end{array}$ & $\begin{array}{c}1.065 \\
(0.773)\end{array}$ & $\begin{array}{l}-0.002 \\
(0.012)\end{array}$ & $\begin{array}{c}-0.015 \\
(0.018)\end{array}$ & $\begin{array}{l}-11.461 \\
(31.982)\end{array}$ & $\begin{array}{l}-0.015 \\
(0.021)\end{array}$ \\
\hline Same-State Death, 1 & $\begin{array}{c}7.461 \\
(4.178)\end{array}$ & $\begin{array}{c}1.104 \\
(0.697)\end{array}$ & $\begin{array}{c}0.011 \\
(0.011)\end{array}$ & $\begin{array}{l}-0.032^{*} \\
(0.016)\end{array}$ & $\begin{array}{c}-4.046 \\
(24.799)\end{array}$ & $\begin{array}{l}-0.009 \\
(0.018)\end{array}$ \\
\hline Legislator FE & Yes & Yes & Yes & Yes & Yes & Yes \\
\hline Congress FE & Yes & Yes & Yes & Yes & Yes & Yes \\
\hline Controls & Yes & Yes & Yes & Yes & Yes & Yes \\
\hline Mean Dependent Variable & 190.55 & 15.42 & 0.05 & 0.24 & 636.78 & 0.57 \\
\hline Observations & 6134 & 6134 & 6564 & 6564 & 6327 & 6564 \\
\hline
\end{tabular}

Note: The dependent variables in Columns 1-6 are 1) the number of bills cosponsored by the legislator, 2) the average number of cosponsors obtained by bills sponsored by the legislator, 3) an indicator variable for committee chair, 4) an indicator variable for subcommittee chair, 5) contributions received from PACs and individuals, and 6) an indicator variable for majority party status, respectively. The unit of observation is a legislator-congress. Standard errors (in parentheses) are clustered at the legislator level. Significance levels: * $\%$, ** $1 \%$

tributions lawmakers receive from PACs and individuals (Column 5 of Table 7). Finally, Column 6 indicates that legislators from the same states as deceased legislators did not transition into or out of majority status at significantly different rates than all other legislators. This finding is not surprising, but given that majority status is a major driver of legislative effectiveness, it is important to ensure that treatment status does not correlate with changes in the partisan control of the House and concomitant changes in lawmakers' majority status. 


\section{Reelection, Attendance, and Party Loyalty}

Columns 1-4 of Table 8 show that the decrease in effectiveness caused by the deaths of same-state legislators did not significantly affect lawmakers' reelection probabilities. The dependent variable is an indicator that takes value 1 if the lawmaker is reelected at the end of a congressional term. The independent variables are Same-State Death ${ }_{i, 0}$ (Columns 1 and 2) and Same-State Death ${ }_{i, 1}$ (Columns 3 and 4). Columns 1 and 2 test whether the death of a same-state legislator affects reelection rates at the end of the congress in which the deaths take place. Columns 3 and 4 test reelection rates at the end of the congress after the deaths take place. ${ }^{29}$ First-term legislators are excluded from the regression in Columns 3 and 4 so that treatment and control legislators are comparable-lawmakers impacted by the death of a same-state legislator in the previous congress constitute a selected sample that does not include first-term lawmakers nor lawmakers not reelected in the previous term. If anything, the results show that lawmakers impacted by same-state deaths are reelected at slightly higher rates in the congress after the deaths. Either voters do not punish their representatives for their decrease in effectiveness, or same-state legislators shift resources away from lawmaking and into district activities and events to fend off any possible electoral penalty associated with a decreased congressional influence. The latter behavior would be consistent with Grimmer and Powell (2013), who find that lawmakers that lose power in Washington-due to involuntary removals from committees—shift resources to their districts and avoid an electoral penalty.

In Columns 5 and 6 of Table 8 I investigate this hypothesis: namely, that lawmakers affected by deaths of same-state legislators shift efforts from D.C to their districts in response to their decreased influence in Congress. To this end, I examine how many days these lawmakers are absent from Congress and their party unity scores. ${ }^{30}$ The

\footnotetext{
${ }^{29}$ The regression includes state and congress fixed effects. State fixed effects account for differences across states in the incumbency advantage and propensity to be impacted by same-state deaths.

${ }^{30}$ I follow Grimmer and Powell (2013) and assume a lawmaker was absent from Congress if she missed
} 
Table 8: Reelection, Attendance, and Party Loyalty

\begin{tabular}{|c|c|c|c|c|c|c|}
\hline & \multicolumn{4}{|c|}{ Reelection } & \multirow{2}{*}{$\begin{array}{c}\text { Days } \\
\text { Absent } \\
(5)\end{array}$} & \multirow{2}{*}{$\begin{array}{c}\text { Party } \\
\text { Unity } \\
(6)\end{array}$} \\
\hline & (1) & (2) & (3) & (4) & & \\
\hline Same-State Death, -1 & & & & & $\begin{array}{l}-0.011 \\
(0.031)\end{array}$ & $\begin{array}{c}0.198 \\
(0.315)\end{array}$ \\
\hline Same-State Death, 0 & $\begin{array}{c}0.000 \\
(0.014)\end{array}$ & $\begin{array}{l}-0.002 \\
(0.014)\end{array}$ & & & $\begin{array}{l}-0.031 \\
(0.036)\end{array}$ & $\begin{array}{c}0.319 \\
(0.311)\end{array}$ \\
\hline Same-State Death, 1 & & & $\begin{array}{c}0.026 \\
(0.016)\end{array}$ & $\begin{array}{c}0.023 \\
(0.015)\end{array}$ & $\begin{array}{l}-0.061 \\
(0.033)\end{array}$ & $\begin{array}{c}0.164 \\
(0.281)\end{array}$ \\
\hline State FE & Yes & Yes & Yes & Yes & No & No \\
\hline Legislator FE & No & No & No & No & Yes & Yes \\
\hline Congress FE & Yes & Yes & Yes & Yes & Yes & Yes \\
\hline Controls & No & Yes & No & Yes & Yes & Yes \\
\hline Mean Dependent Variable & 0.85 & 0.85 & 0.85 & 0.85 & 1.85 & 86.29 \\
\hline Observations & 7047 & 7032 & 5964 & 5950 & 6564 & 6555 \\
\hline
\end{tabular}

Note: Columns 1-4 report the results of regressing incumbent reelection on same-state death, with state and congress fixed effects. Columns 3 and 4 exclude first-term legislators. The dependent variables in Columns 5 and 6 are $\log (1+$ number of days a lawmaker was absent from Congress) and the party unity score of the lawmaker, respectively. The control variables are the standard ones (vote share is excluded in Columns 1-4). The unit of observation is a legislator-congress. Standard errors (in parentheses) are clustered at the legislator level. Significance levels: ${ }^{*} 5 \%,{ }^{* *} 1 \%$ 
results show that same-state legislators miss fewer days in session (Column 5, borderline significant) and do not experience any significant change in their party unity scores. Thus, the evidence does not indicate that same-state legislators turn their attention to their district. Instead, the findings on congressional attendance suggest that same-state legislators exert more effort in Congress to make up for the lost connection and influence, which is consistent with the findings in Columns 1 and 2 of Table 7.

\section{Cross-Chamber Effects}

Volden and Wiseman (2014) emphasize the value of cross-chamber relations for legislative effectiveness. Bills that eventually become law need support from the House and the Senate. Sometimes bills go back and forth between the chambers as amendments are added and compromise versions are negotiated in special conference committees. In this environment, having reliable allies in the Senate can prove crucial to ensure a bill succeeds in the later lawmaking stages.

In the same way that lawmakers from the same state delegation collaborate more often in the House, state ties facilitate legislative connections and collaboration between same-state Senators and House representatives. In Figure 4 below, I consider how deaths in office of Senators and members of the House impact the effectiveness of same-state House legislators. ${ }^{31}$ The results show that deaths in office of Senators also decrease same-state House representatives' legislative effectiveness-the coefficient on Same-State Death ${ }_{i, 1}$ is now -0.19 (versus -0.16 in Column 5 of Table 3). Senators are influential lawmakers, and it is not surprising to find that their deaths have impacts beyond their chamber.

all roll-call votes of a day. The dependent variable is in logs, as "Days Absent" is skewed. Party unity scores measure the percentage of roll-call votes in which lawmakers vote with their party, and were obtained from Voteview (Lewis et al., 2017).

${ }^{31}$ Figure 4 is analogous to Figure 1, except that it also includes House representatives impacted by deaths of same-state Senators in the treatment group. 12 Senators died in office during the period of analysis (Table B.2). 
Figure 4: Effect of the Death of a Same-State Representative or Senator on Effectiveness

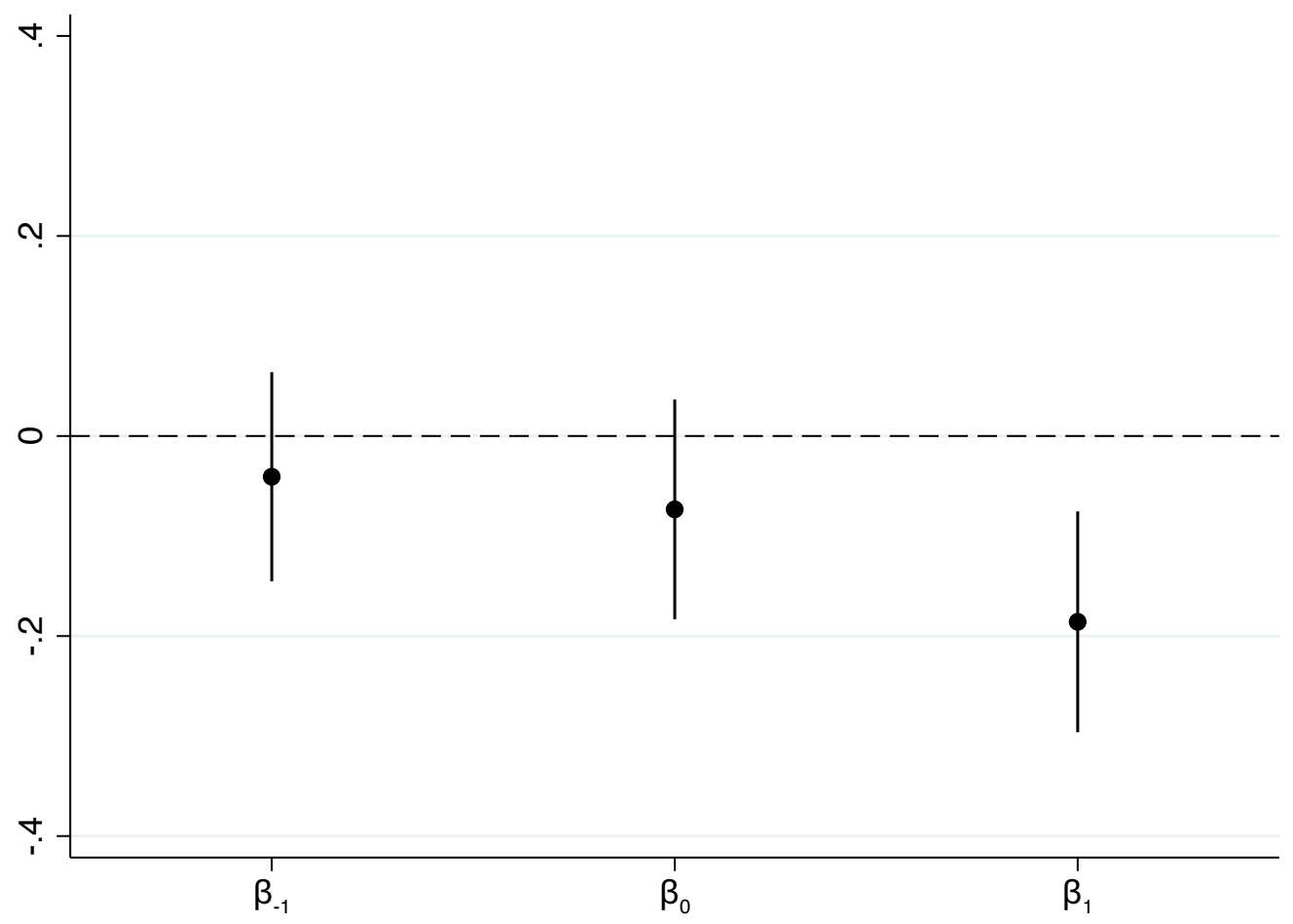

Note: This figure depicts the $\beta$ estimates of equation 3 when considering the deaths of both House Representatives and Senators.

\section{Conclusions}

Legislative connections in the U.S. House of Representatives help lawmakers advance their bills and become effective. Most bills introduced in the House are never considered in committee, and a network of powerful connections who can pressure the relevant committee members and committee chairs constitutes an invaluable lawmaking asset. I show that the death of a lawmaker in office significantly decreases same-state legislators' effectiveness: their bills become less likely to be considered in committee and are ultimately less likely to become law. The effects are stronger when the deceased legislator was the chair of a committee-a powerful and influential lawmaker.

Collaborations in Congress arise endogenously, which constitutes a major challenge for identifying the causal effects of connections or networks on political outcomes (Ro- 
gowski and Sinclair, 2012). To learn how legislative connections impact voting behavior and lawmaking in Congress, studies that leverage quasi-random variation in connections are needed. The design in this paper draws inferences about the effects of connections by comparing the performance of otherwise balanced samples that are differentially exposed to disruptions in their legislative connections. Lawmakers' deaths in office result in abrupt and unexpected disruptions to collaboration networks in the legislature. Membership in the same state delegation induces differential exposure to such disruptions.

The effectiveness spillovers identified in this paper cross party lines. Legislative collaborations between lawmakers from different parties are valuable, even if these collaborations arise less frequently than copartisan collaborations. In times of increasing political polarization in Congress, cross-party legislative collaborations help to secure broader support for pressing policy reforms. Former Representative Beto O'Rourke of Texas recently shared an anecdote that illustrates the importance of cross-party collaborations. It also exemplifies how representing the same state can facilitate contact and spur legislative collaborations. On October 15th, 2019, in the Democratic presidential primary debate that took place in Westerville, $\mathrm{OH}, \mathrm{O}^{\prime}$ Rourke was asked about his most surprising friendship. He recalled the time he became friends with Representative Will Hurd of Texas, when both of them were in the San Antonio airport in March 2017 and their flight to Washington, DC was canceled due to an East Coast blizzard. He asked Hurd if he would agree to rent a car with him and drive to DC together. Hurd accepted the offer, and a strong bond was formed between the two lawmakers as a result of the grueling 25-hour road trip. Their friendship became stronger over time, and resulted in legislative collaborations in, among other issues, a bipartisan immigration bill. The serendipitous story behind this example of bipartisan cooperation constitutes one of many ways in which representing the same state can lead to increased contact and subsequent collaboration. It also emphasizes the value of cross-party friendships and cooperation in times of strong partisanship, polarization, and political hostility. 


\section{References}

Adler, E. Scott and John Wilkerson, "Congressional Bills Project," 2015, Available at www . congressionalbills. org.

Ainsworth, Scott H. and Frances Akins, "The Informational Role of Caucuses in the U.S. Congress," American Politics Quarterly, 1997, Vol. 25, 4, pp. 407-430.

Anderson, William D., Janet M. Box-Steffensmeier and Valeria Sinclair-Chapman, “The Keys to Legislative Success in the U.S. House of Representatives," Legislative Studies Quarterly, 2003, Vol. 28, 3, pp. 357-386.

Azoulay, Pierre, Joshua S. Graff-Zivin and Jialan Wang, "Superstar Extinction," Quarterly Journal of Economics, 2010, Vol. 125, pp. 549-589.

Battaglini, Marco, Valerio Leone Sciabolazza and Eleonora Patacchini, "Effectiveness of Connected Legislators," American Journal of Political Science, 2019, forthcoming.

Battaglini, Marco and Eleonora Patacchini, "Influencing Connected Legislators," Journal of Political Economy, 2018, Vol. 126, 6, pp. 2277-2322.

Bernhard, William and Tracy Sulkin, "Commitment and Consequences: Reneging on Cosponsorship Pledges in the U.S. House," Legislative Studies Quarterly, 2013, Vol. 38, 4, pp. 461-487.

Berry, Christopher R. and Anthony Fowler, "Congressional Committees, Legislative Influence, and the Hegemony of Chairs," Journal of Public Economics, 2018, Vol. 158, pp. $1-11$.

Bonica, Adam, "Database on Ideology, Money in Politics, and Elections: Public Version 2.0," Stanford, CA: Stanford University Libraries https://data. stanford.edu/dime.

Box-Steffensmeier, Janet M., Dino P. Christenson and Alison W. Craig, "Cue-Taking in Congress: Interest Group Signals From Dear Colleague Letters," American Journal of Political Science, 2019, Vol. 63, 1, pp. 163-180. 
Box-Steffensmeier, Janet M., Benjamin W. Campbell, Andrew W. Podob and Seth J. Walker, "I Get By With a Little Help from My Friends: Leveraging Campaign Resources to Maximize Congressional Power," American Journal of Political Science, forthcoming.

Bratton, Kathleen A. and Stella M. Rouse, "Networks in the Legislative Arena: How Group Dynamics Affect Cosponsorship," Legislative Studies Quarterly, 2011, Vol. 36, 3, pp. $423-460$.

Caldeira, Gregory A. and Samuel C. Patterson, "Political Friendship in the Legislature," Journal of Politics, 1987, Vol. 49, 4, pp. 953-975.

Canen, Nathan, Matthew O. Jackson and Francesco Trebbi, “Endogenous Networks and Legislative Activity," Unpublished Manuscript, https://papers.ssrn.com/sol3/ papers.cfm?abstract_id=2823338, 2020.

Cohen, Lauren and Christopher J. Malloy, "Friends in High Places," American Economic Journal: Economic Policy, 2014, Vol. 6, 3, pp. 63-91.

Cox, Gary W. and William C. Terry, "Legislative Productivity in the 93d-105th Congresses," Legislative Studies Quarterly, 2008, Vol. 33, 4, pp. 603-618.

Fedaseyeu, Viktar and Lev Lvovskiy, "The Value of Corporate Political Connections: Evidence from Sudden Deaths," Unpublished Manuscript, https://papers.ssrn.com/ sol3/papers. cfm?abstract_id=3040039, 2018.

Fenno, Richard F., Jr., “Congressmen in Committees," 1973, Boston: Little, Brown and Company.

Fenno, Richard F., Jr., "Home Style: House Members in their Districts," 1978, Boston: Little, Brown and Company.

Fong, Christian, "Expertise, Networks, and Interpersonal Influence in Congress," Journal of Politics, 2019, forthcoming. 
Fouirnaies, Alexander and Andrew B. Hall, "How Do Electoral Incentives Affect Legislator Behavior?," Unpublished Manuscript, http://www.andrewbenjaminhall.com/ Fouirnaies_Hall_Electoral_Incentives.pdf, 2018.

Fowler, James H., "Connecting the Congress: A Study of Cosponsorship Networks," Political Analysis, 2006a, Vol. 14, 4, pp. 456-487.

Fowler, James H., "Legislative Cosponsorship Networks in the US House and Senate," Social Networks, 2006b, Vol. 28, pp. 454-465.

Frantzich, Stephen, "Who Makes Our Laws? The Legislative Effectiveness of Members of the U.S. Congress," Legislative Studies Quarterly, 1979, Vol. 4, pp. 409-428.

Grimmer, Justin and Eleanor Neff Powell, "Congressmen in Exile: The Politics and Consequences of Involuntary Committee Removal," Journal of Politics, 2013, Vol. 75, 4, pp. 907-920.

Harbridge, Laurel, "Is Bipartisanship Dead? Policy Agreement and Agenda-Setting in the House of Representatives," 2015, Cambridge University Press.

Harmon, Nikolaj, Raymond Fisman and Emir Kamenica, "Peer Effects in Legislative Voting," American Economic Journal: Applied Economics, 2019, Vol. 11, 4, pp. 156-180.

Heberlig, Eric, "Congressional Parties, Fundraising, and Committee Ambition," Political Research Quarterly, 2003, Vol. 56, 2, pp. 151-161.

Hibbing, John, "Congressional Careers: Contours of Life in the U.S. House of Representatives," 1991, University of North Carolina Press.

Kirkland, Justin, "The Relational Determinants of Legislative Outcomes: Strong and Weak Ties Between Legislators," Journal of Politics, 2011, Vol. 73, 3, pp. 887-898.

Koger, Gregory, "Position Taking and Cosponsorship in the U.S. House," Legislative Studies Quarterly, 2003, Vol. 28, 2, pp. 225-246. 
Krehbiel, Keith, "Information and Legislative Organization," 1992, University of Michigan Press.

Lewis, Jeffrey B., Keith Poole, Howard Rosenthal, Adam Boche, Aaron Rudkin, Luke Sonnet, "Voteview: Congressional Roll-Call Votes Database," 2017, https://voteview. com/.

Lorenz, Geoffrey M., “Prioritized Interests: Diverse Lobbying Coalitions and Congressional Committee Agenda Setting," Journal of Politics, 2020, Vol. 82, 1, pp. 225-240.

Maltzman, Forrest, Lee Sigelman, and Sarah Binder, "Leaving Office Feet First: Death in Congress," PS: Political Science and Politics, 1996, Vol. 29, 4, pp. 665-671.

Masket, Seth E., "Where You Sit Is Where You Stand: The Impact of Seating Proximity on Legislative Cue-Taking," Quarterly Journal of Political Science, 2008, Vol. 3, pp. 301-311. Matthews, Donald R., “United States Senators and Their World," 1960, New York: Random House.

Matthews, Donald R. and James A. Stimson, "Yeas and Nays: Normal Decision-Making in the U.S. House of Representatives," 1975, Wiley-Interscience.

Mayhew, David R., “Congress: The Electoral Connection,” 1974, New Haven: Yale University Press.

McCarty, Nolan, Keith T. Poole and Howard Rosenthal, "Polarized America: The Dance of Ideology and Unequal Riches," 2016, MIT Press.

Minozzi, William and Gregory A. Caldeira, "Social Influence in the U.S. House of Representatives, 1801-1861," Unpublished Manuscript, https://pdfs.semanticscholar. org/67eb/7d32663c6e7b771c5d9df6d27ec57df5e3b9.pdf, 2015.

Padró i Miquel, Gerard and James M. Snyder, Jr., "Legislative Effectiveness and Legislative Careers," Legislative Studies Quarterly, 2006, Vol. 31, 3, pp. 347-381. 
Pellegrini, Pasquale A. and J. Tobin Grant, "Policy Coalitions in the US Congress: A Spatial Duration Modeling Approach," Geographical Analysis, 1999, Vol. 31, 1, pp. 45-66.

Roberts, Brian E., "A Dead Senator Tells No Lies: Seniority and the Distribution of Federal Benefits," American Journal of Political Science, 1990, Vol. 34, 1, pp. 31-58.

Rogowski, Jon C. and Betsy Sinclair, "Estimating the Causal Effects of Social Interaction with Endogenous Networks," Political Analysis, 2012, Vol. 20, 3, pp. 316-328.

Tam Cho, Wendy K. and James H. Fowler, "Legislative Success in a Small World: Social Network Analysis and the Dynamics of Congressional Legislation," Journal of Politics, 2010, Vol. 72, 1, pp. 124-135.

Victor, Jennifer Nicoll and Nils Ringe, "The Social Utility of Informal Institutions: Caucuses as Networks in the 110th United States House of Representatives," American Politics Research, 2009, Vol. 37, 5, pp. 742-766.

Volden, Craig and Alan E. Wiseman, "Legislative Effectiveness in the United States Congress: The Lawmakers," 2014, New York: Cambridge University Press.

Wilson, Rick K. and Cheryl D. Young, "Cosponsorship in the U.S. Congress," Legislative Studies Quarterly, 1997, Vol. 22, 1, pp. 25-43. 


\section{Online Appendix:}

The Role of Connections in Congressional Lawmaking 


\section{Contents}

$\begin{array}{ll}\text { A Data Sources } & 3\end{array}$

B List of Legislators in Congress that Died in Office $\quad 4$

$\begin{array}{lr}\text { C Endogenous Connections } & 6\end{array}$

D Legislators from the Same State Collaborate More Often 13

$\begin{array}{llr}\text { E Additional Figures and Tables } & 15\end{array}$ 


\section{A Data Sources}

Legislative effectiveness data were obtained from the Legislative Effectiveness Project by Craig Volden and Alan E. Wiseman (Center for Effective Lawmaking, https:// thelawmakers.org/). These data contain yearly legislative effectiveness scores for each legislator in the U.S. House of Representatives. They also contain various legislatorlevel covariates used in the paper. These include seniority, vote share in the last general election, majority membership, size of the state delegation, legislative committee membership, and committee and subcommittee chair positions. Data on bill sponsorship and cosponsorship were obtained from the Cosponsorship Network Data by James H. Fowler, Andrew Scott Waugh, and Yunkyu Sohn (http://jhfowler.ucsd. edu/cosponsorship.htm). Data on deaths in office of legislators were obtained from Fedaseyeu and Lvovskiy (2018), and PAC contributions data come from Adam Bonica's DIME dataset (https://data.stanford.edu/dime).

Data on bill issues were obtained from the Congressional Bills Project by E. Scott Adler and John Wilkerson (http://www. congressionalbills.org/). The Congressional Bills Project categorizes each House bill into one of 22 issues: Macroeconomics, Civil Rights, Health, Agriculture, Labor, Education, Environment, Energy, Immigration, Transportation, Law and Crime, Social Welfare, Housing, Domestic Commerce, Defense, Technology, Foreign Trade, International Affairs, Government Operations, Public Lands, Culture, and Other. 


\section{B List of Legislators in Congress that Died in Office}

Table B.1: U.S. House Representatives Deceased in Office

\begin{tabular}{|c|c|c|}
\hline Name of Legislator & Congress & Election Cycle \\
\hline John M. Slack (WV) & 96 & 1980 \\
\hline $\begin{array}{l}\text { John M. Ashbrook }(\mathrm{OH}) \text {, Adam Benjamin, Jr. }(\mathrm{IN}) \text {, } \\
\text { William R. Cotter }(\mathrm{CT}) \text {, Tennison Guyer }(\mathrm{OH})\end{array}$ & 97 & 1982 \\
\hline $\begin{array}{l}\text { Phillip Burton (CA), Edwin B. Forsythe (NJ), } \\
\text { Lawrence P. McDonald (GA), Carl D. Perkins (KT), } \\
\text { Benjamin S. Rosenthal (NY), Clement J. Zablocki (WI) }\end{array}$ & 98 & 1984 \\
\hline Joseph P. Addabbo (NY), Gillis Long (LA) & 99 & 1986 \\
\hline $\begin{array}{l}\text { Sala Burton (CA), Dan Daniel (VA), John J. Duncan (TN), } \\
\text { James J. Howard (NJ), Stewart B. McKinney (CT), } \\
\text { Bill Nichols (AL), Melvin Price (IL) }\end{array}$ & 100 & 1988 \\
\hline Mickey Leland (TX), Claude D. Pepper (FL), Larkin I. Smith (MS) & 101 & 1990 \\
\hline Silvio O. Conte (MA), Walter Jones (NC), Ted Weiss (NY) & 102 & 1992 \\
\hline Paul B. Henry (MI), William Natcher (KY) & 103 & 1994 \\
\hline Bill Emerson (MO) & 104 & 1996 \\
\hline Sonny Bono (CA), Walter Capps (CA), Frank Tejeda (TX), Steve Schiff (NM) & 105 & 1998 \\
\hline Julian Dixon (CA) & 106 & 2000 \\
\hline Patsy T. Mink (HI), Norman Sisisky (VA) & 107 & 2002 \\
\hline Robert Matsui (CA) & 109 & 2006 \\
\hline $\begin{array}{l}\text { Julia M. Carson (IN), Jo Ann Davis (VA), Paul E. Gillmor (OH), } \\
\text { Stephanie Tubbs Jones (OH), Tom Lantos (CA), } \\
\text { Juanita Millender-McDonald (CA), Charlie Norwood (GA) }\end{array}$ & 110 & 2008 \\
\hline John P. Murtha (PA) & 111 & 2010 \\
\hline
\end{tabular}

Note: From Fedaseyeu and Lvovskiy (2018). Rosenthal and Matsui died on January 4, 1983 and January 1, 2005, respectively, so I coded their death years as 1982 and 2004. 
Table B.2: U.S. Senators Deceased in Office

\begin{tabular}{lll}
\hline Name of Senator & Congress & Election Cycle \\
\hline Henry M. Jackson (WA) & 98 & 1984 \\
John P. East (NC) & 99 & 1986 \\
Edward Zorinsky (NE) & 100 & 1988 \\
Spark Matsunaga (HI) & 101 & 1990 \\
John Heinz (PA), Quentin N. Burdick (ND) & 102 & 1992 \\
John H. Chafee (RI), Paul D. Coverdell (GA) & 106 & 2000 \\
Paul D. Wellstone (MN) & 107 & 2002 \\
Craig L. Thomas (WY) & 110 & 2008 \\
Edward Kennedy (MA), Robert C. Byrd (WV) & 111 & 2010 \\
& & \\
\hline
\end{tabular}




\section{Endogenous Connections}

The death of a legislator while in office constitutes an abrupt disruption to legislative networks, which should be felt especially by lawmakers connected to the deceased legislator. Accordingly, a natural first attempt to identify the effects of losing a legislative connection on effectiveness is to examine how the effectiveness of connected legislators changes - compared with non-connected legislators-after a legislator passes away. Several measures of connections between legislators have been used to date, all of which are based on cosponsorship patterns (Fowler, 2006a, 2006b; Battaglini, Sciabolazza and Patacchini, 2019). Legislators who cosponsor the same bills more often, or who frequently cosponsor each other's bills, are considered to be more connected. Bills in the House can only have a legislator as the sponsor, but there are no restrictions on the number of cosponsors. Cosponsoring a bill is considered as an endorsement, a signal about its content (Wilson and Young, 1997; Koger, 2003; Bratton and Rouse, 2011), and a commitment of support (Bernhard and Sulkin, 2013).

In line with the preceding discussion, I estimate the following model

$$
\text { Effectiveness }_{i t}=\alpha_{i}+\delta_{t}+\sum_{s=-1}^{1} \beta_{s} \text { Connection }_{i, s}+\gamma X_{i t}+\epsilon_{i t}
$$

where Effectiveness it $_{\text {it }}$ denotes the legislative effectiveness score of legislator $i$ in congress $t, \alpha_{i}$ and $\delta_{t}$ denote legislator and congress fixed effects, and $X_{i t}$ denotes a set of legislator-level controls. and Connection ${ }_{i,-1}$ measures the degree of connection of legislator $i$ with legislators deceased while in office in the next congress. Connection $n_{i, 0}$ measures the degree of connection of legislator $i$ in the previous congress with legislators deceased while in office in that congress. Connection $_{i, 1}$ measures the degree of connection of legislator $i$ in the congress before the deaths with legislators deceased while in office in the previous congress. The sample spans the 1980 to 2010 election cycles, and 
includes the deaths of 45 legislators. ${ }^{32}$ Standard errors are clustered at the legislator level to account for arbitrary within-legislator correlation.

The effectiveness scores of each legislator in each congress are obtained from the Legislative Effectiveness Project (Volden and Wiseman, 2014). The scores are calculated as weighted sums of the number of bills sponsored by a legislator in a congress, the importance of those bills, and how far they advanced through the lawmaking stages. The scores are normalized so that the mean score in each congress is equal to 1 . Table C.1 in the Appendix reports the results of estimating equation C.1. For the first two columns, the measure of connection is the number of cosponsorships received by deceased legislators. For Columns 3 and 4, it is the number of reciprocal cosponsorship with deceased legislators. ${ }^{33}$ Both measures of connection are calculated for the congress before the legislator passed away. ${ }^{34}$ Legislator fixed effects, $\alpha_{i}$, are included to account for time-invariant, legislator-level traits that impact effectiveness and connections. Congress fixed effects, $\delta_{t}$, account for yearly common shocks. The control variables, $X_{i t}$, include seniority and its squared value to control for common non-linear effectiveness trajectories throughout legislators' careers; an indicator variable for majority membership; size of the state delegation; vote share in the previous general election; and indicator variables for whether the legislator was the chair of a committee, chair of a subcommittee, or member of a powerful committee (Rules, Appropriations, and Ways and Means). These last control variables account for changes in legislative effectiveness scores attributable to changes in the institutional positions of legislators. Majority status, seniority, electoral security, committee leadership positions, and membership in powerful committees are major determinants of effectiveness (Volden and Wiseman, 2014). ${ }^{35}$

\footnotetext{
${ }^{32}$ The list of legislators who died in office during this period is in Table B.1

${ }^{33}$ The reciprocal cosponsorship variable is calculated as $\min \left\{\operatorname{Cos} p_{i j}, \operatorname{Cos} p_{j i}\right\}$, in which $\operatorname{Cos} p_{i j}$ and $\operatorname{Cos} p_{j i}$ denote the number of bills sponsored by legislator $j$ and cosponsored by legislator $i$, and vice versa.

${ }^{34}$ If legislator $i$ was connected to more than one deceased legislator in a given congress, the connection variable is the sum of the connections to each deceased legislator.

${ }^{35}$ The size of the state delegation is mostly constant over time, and thus absorbed by the legislator fixed effects. However, it sometimes changes after redistricting as a result of changes in population across states.
} 
Table C.1: Effect of Death of Connected Legislator on Effectiveness

\begin{tabular}{lcccc}
\hline & \multicolumn{3}{c}{ Legislative Effectiveness } \\
\cline { 2 - 5 } & $(1)$ & $(2)$ & $(3)$ & $(4)$ \\
\hline Cosponsorships Received, -1 & $0.075^{* *}$ & $0.060^{* *}$ & & \\
& $(0.012)$ & $(0.010)$ & & \\
Cosponsorships Received, 0 & $0.063^{* *}$ & $0.036^{* *}$ & & \\
& $(0.014)$ & $(0.011)$ & & \\
Cosponsorships Received, 1 & $0.046^{* *}$ & 0.011 & & $0.054^{*}$ \\
& $(0.013)$ & $(0.011)$ & & 0.032 \\
Reciprocal Cosponsorships, -1 & & & $(0.027)$ & $(0.021)$ \\
& & & $0.154^{* *}$ & $0.095^{* *}$ \\
Reciprocal Cosponsorships, 0 & & & $(0.026)$ & $(0.022)$ \\
& & & $0.110^{* *}$ & 0.034 \\
Reciprocal Cosponsorships, 1 & & & $(0.029)$ & $(0.023)$ \\
& & & Yes & Yes \\
Legislator FE & Yes & Yes & Yes & Yes \\
Congress FE & Yes & Yes & No & Yes \\
Controls & No & Yes & 6800 & 6564 \\
Observations & 6800 & 6564 & \\
\hline
\end{tabular}

Note: The table reports the results of estimating equation C.1. The unit of observation is a legislator-congress. Standard errors (in parentheses) are clustered at the legislator level. Significance levels: ${ }^{*} 5 \%,{ }^{* *} 1 \%$

The results in Table C.1 in the Appendix suggest, at first glance, that losing a connection enhances effectiveness. However, the lead variables in Columns 1 and 2 are positive and significant, which indicates that lawmakers connected to deceased legislators disproportionately increase their effectiveness scores-relative to non-connected legislators-in the congress before the connected legislator died. This constitutes a violation of the pre-treatment parallel trends condition, which puts the validity of the research design into question. Furthermore, Table C.2 in the Appendix shows that the balance test does not hold. ${ }^{36}$ Even after controlling for seniority and all other covari-

\footnotetext{
${ }^{36}$ The balance test in Table C.2 estimates equation

$$
\text { Effectiveness }_{i t}=\delta_{t}+\beta_{0} \text { Connection }_{i, 0}+\gamma X_{i t}+\epsilon_{i t}
$$
}


ates, legislators who receive larger treatments-legislators who were strongly connected to the deceased-are systematically more effective than legislators less connected to the deceased. Relative to their peers, well-connected lawmakers experience differing trends in their effectiveness scores. These unequal career patterns are not fully captured by the legislator fixed effects. As a result, pre-treatment trends between affected and unaffected lawmakers diverge. The balance test illustrates that connections are not random. It is crucial to properly account for the endogenous formation of connections to avoid misleading inferences.

Table C.2: Balance Table for Connection Variables

\begin{tabular}{lcccccc}
\hline & \multicolumn{6}{c}{ Legislative Effectiveness } \\
\cline { 2 - 7 } & $(1)$ & $(2)$ & $(3)$ & $(4)$ & $(5)$ & $(6)$ \\
\hline Cosponsorships Received & $0.149^{* *}$ & $0.093^{* *}$ & $0.060^{* *}$ & & & \\
& $(0.016)$ & $(0.014)$ & $(0.011)$ & & & \\
Reciprocal Cosponsorships & & & & $0.286^{* *}$ & $0.192^{* *}$ & $0.120^{* *}$ \\
& & & & $(0.037)$ & $(0.033)$ & $(0.029)$ \\
Seniority & & $0.142^{* *}$ & $0.051^{* *}$ & & $0.147^{* *}$ & $0.057^{* *}$ \\
& & $(0.013)$ & $(0.019)$ & & $(0.013)$ & $(0.018)$ \\
\hline Legislator FE & No & No & No & No & No & No \\
Congress FE & Yes & Yes & Yes & Yes & Yes & Yes \\
Controls & No & No & Yes & No & No & Yes \\
Observations & 7048 & 7034 & 6827 & 7048 & 7034 & 6827 \\
\hline
\end{tabular}

Note: The table reports a balance test of legislators differentially connected to the deceased. The unit of observation is a legislator-congress. Standard errors (in parentheses) are clustered at the legislator level. Significance levels: ${ }^{*} 5 \%,{ }^{* *} 1 \%$

As further evidence of the lack of validity of the research design, Figures C.1 and C.2 in the Appendix plot the distribution of placebo estimates of $\beta_{s}$ for cosponsorships received and reciprocal consponsorships with deceased lawmakers. Each placebo estimate is obtained by randomly selecting a set of 45 legislators at certain congresses as deceased, and computing the resulting connection variables for all other legislators based on acwhich does not include legislator fixed effects. 
tual collaboration data. ${ }^{37}$ The placebo distributions for the estimates associated with the connection variables are all far from centered around zero. Even if the simulated sets of deceased legislators are chosen randomly, the legislators connected to them do not constitute a random group. Well-connected and powerful legislators are overrepresented relative to their peers.

\footnotetext{
${ }^{37}$ The legislators who died in office were more senior than the average legislator in the U.S. House of Representatives. Accordingly, in the placebo simulations, I randomly select sets of deceased legislators from the pool of legislators who were serving their fourth term in office, or a subsequent term. With this constraint, the seniority of the simulated sets of deceased legislators is similar to that of the actually deceased.
} 
Figure C.1: Placebo Distributions for Cosponsorships Received

(a) Distribution of Cosponsorships Received $_{i,-1}$ estimates

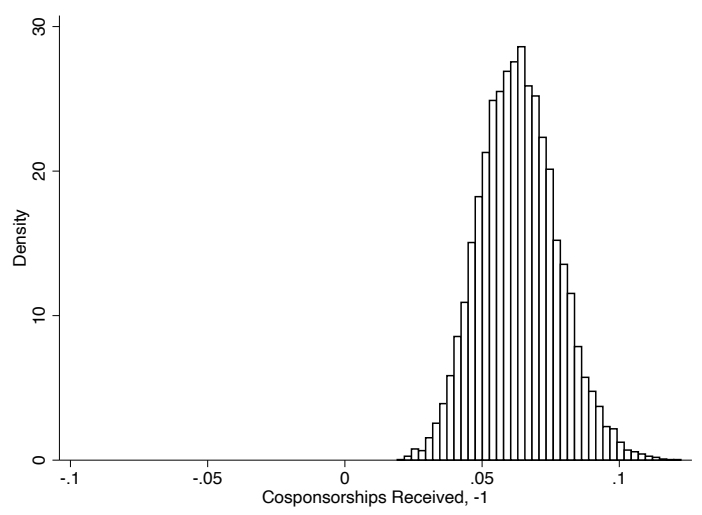

(b) Distribution of Cosponsorships Received Re $_{, 0}$ estimates

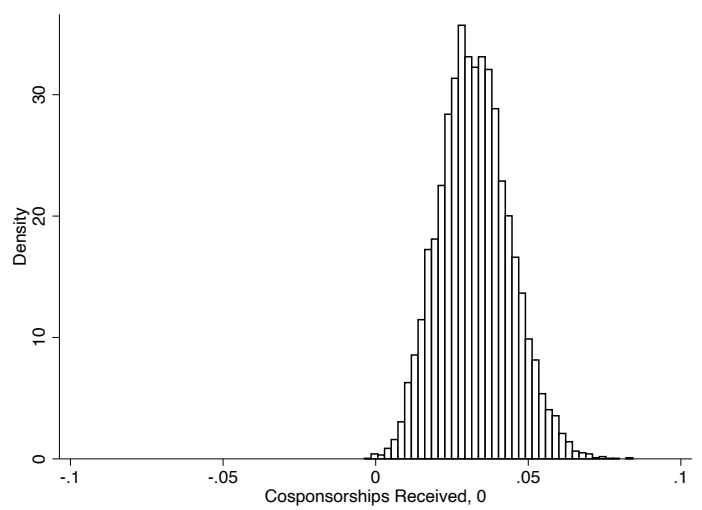

(c) Distribution of Cosponsorships Received $_{i, 1}$ estimates

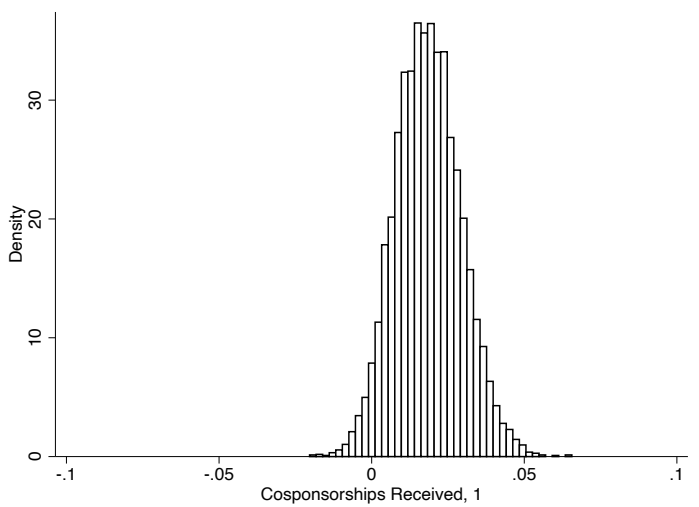

Note: These figures plot the point estimate distributions of the placebo exercises for

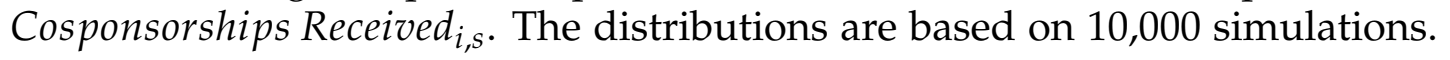


Figure C.2: Placebo Distributions for Reciprocal Cosponsorships $s_{i, s}$

(a) Distribution of Reciprocal Cosponsorships $s_{i,-1}$ estimates

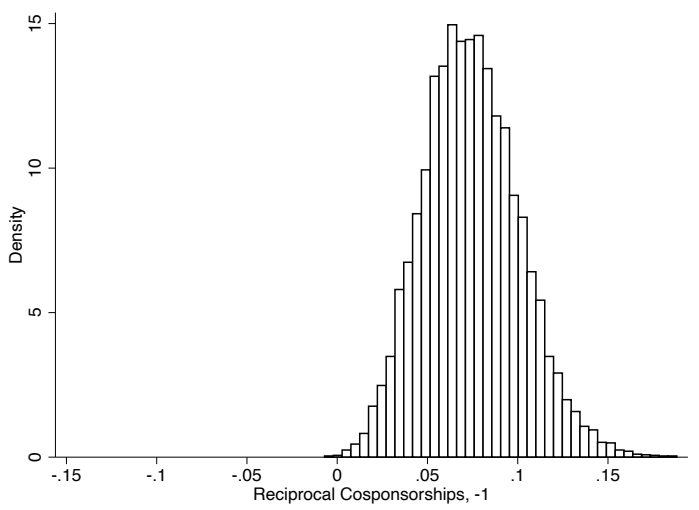

(b) Distribution of Reciprocal Cosponsorships $s_{i, 0}$ estimates

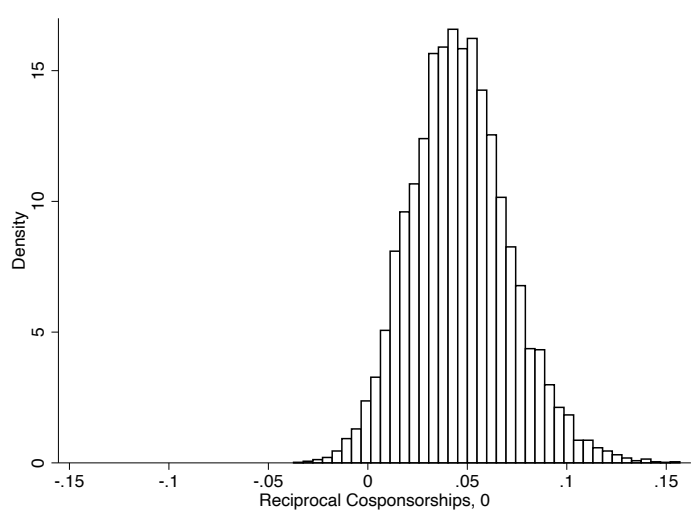

(c) Distribution of Reciprocal Cosponsorships $s_{i, 1}$ estimates

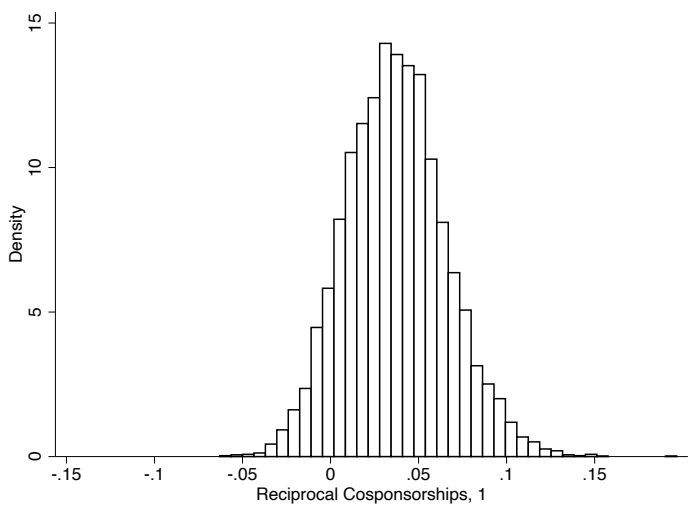

Note: These figures plot the point estimate distributions of the placebo exercises for Reciprocal Cosponsorships ${ }_{i, s}$. The distributions are based on 10,000 simulations. 


\section{Legislators from the Same State Collaborate More Of- ten}

In the main text, I show that lawmakers were indeed more connected to deceased legislators when a legislator from the same state passed away. In Table D.1 below, I show that this pattern of enhanced legislative collaboration with same-state legislators is not limited to legislators deceased in office. Instead, it holds for the full sample of legislators in the House. Table D.1 reports the results of estimating the following regression

$$
\text { Connection }_{i j t}=\alpha+\text { Same State }_{i j t}+\epsilon_{i j t}
$$

where each observation pertains to a dyad formed by legislators $i$ and $j$ in congress $t$. The dependent variable in Columns 1 and 2 is the number of cosponsorships received by a legislator in congress $t$ from the other legislator in the dyad. The dependent variable in Columns 3 and 4 is the number of reciprocal cosponsorships between legislators $i$ and $j$ in congress $t$. The results show that pairs of lawmakers who represent the same states collaborate much more than pairs of lawmakers who represent different states. Likewise, pairs of lawmakers who represent the same party also collaboration more strongly than pairs of lawmakers of different parties. 
Table D.1: Same-State and Same-Party Legislators Collaborate More

\begin{tabular}{lccccc}
\hline & \multicolumn{2}{c}{ Cosponsorships Received } & & \multicolumn{2}{c}{ Reciprocal Cosponsorships } \\
\cline { 2 - 3 } \cline { 5 - 6 } & $(1)$ & $(2)$ & & $(3)$ & $(4)$ \\
\hline Same-State Legislators & $0.809^{* *}$ & $0.807^{* *}$ & & $0.451^{* *}$ & $0.450^{* *}$ \\
& $(0.003)$ & $(0.003)$ & & $(0.001)$ & $(0.001)$ \\
Same-Party Legislators & & $0.348^{* *}$ & & $0.154^{* *}$ \\
& & $(0.001)$ & & $(0.001)$ \\
\hline Mean Dependent Variable & 0.43 & 0.43 & & 0.13 & 0.13 \\
Observations & 2889624 & 2889624 & & 2889624 & 2889624 \\
\hline
\end{tabular}

Note: The unit of observation is a legislator-pair dyad. The dependent variable in Columns 1 and 2 is the number of cosponsorships received by a legislator in congress $t$ from the other legislator in the dyad. The dependent variable in Columns 3 and 4 is the number of reciprocal cosponsorships between legislators $i$ and $j$ in congress $t$. Significance levels: ${ }^{*} 5 \%,{ }^{*} 1 \%$ 


\section{E Additional Figures and Tables}

Table E.1: Main Table with Alternative Clustering

\begin{tabular}{lccc}
\hline & \multicolumn{3}{c}{ Legislative Effectiveness } \\
\cline { 2 - 4 } & $(1)$ & $(2)$ & $(3)$ \\
\hline Same-State Death, -1 & -0.001 & -0.001 & -0.001 \\
& $(0.046)$ & $(0.048)$ & $(0.052)$ \\
Same-State Death, 0 & -0.037 & -0.037 & -0.037 \\
& $(0.054)$ & $(0.048)$ & $(0.055)$ \\
Same-State Death, 1 & $-0.159^{* *}$ & $-0.159^{* *}$ & $-0.159^{* *}$ \\
& $(0.048)$ & $(0.045)$ & $(0.053)$ \\
\hline Legislator FE & Yes & Yes & Yes \\
Congress FE & Yes & Yes & Yes \\
Controls & Yes & Yes & Yes \\
Clustering & State & State-Congress & Legislator and State-Congress \\
Observations & 6564 & 6564 & 6564 \\
\hline
\end{tabular}

Note: The table reports the results of estimating equation 3 with alternative clustering dimensions. Significance levels: ${ }^{*} 5 \%,{ }^{*} 1 \%$ 